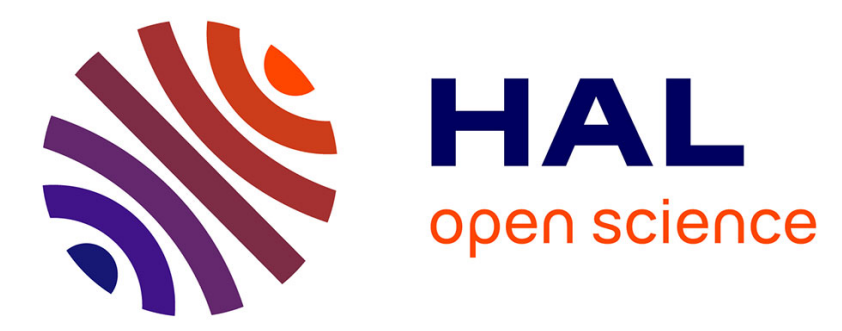

\title{
Comparative study of methods to estimate hydraulic parameters in the hydraulically undisturbed Opalinus Clay
}

Catherine Yu, Jean-Michel Matray, Julio Gonçalvès, David Jaeggi, Werner Gräsle, Klaus Wieczorek, Tobias Vogt, Erik Sykes

\section{To cite this version:}

Catherine Yu, Jean-Michel Matray, Julio Gonçalvès, David Jaeggi, Werner Gräsle, et al.. Comparative study of methods to estimate hydraulic parameters in the hydraulically undisturbed Opalinus Clay. Swiss Journal of Geosciences, 2017, 110, pp.85-104. 10.1007/s00015-016-0257-9 . hal-01501992

\section{HAL Id: hal-01501992 https://hal.science/hal-01501992}

Submitted on 7 Jul 2020

HAL is a multi-disciplinary open access archive for the deposit and dissemination of scientific research documents, whether they are published or not. The documents may come from teaching and research institutions in France or abroad, or from public or private research centers.
L'archive ouverte pluridisciplinaire HAL, est destinée au dépôt et à la diffusion de documents scientifiques de niveau recherche, publiés ou non, émanant des établissements d'enseignement et de recherche français ou étrangers, des laboratoires publics ou privés. 


\section{Swiss Journal of Geosciences}

\section{DB Experiment - Comparative study of methods to estimate hydraulic parameters in the hydraulically undisturbed Opalinus Clay \\ --Manuscript Draft--}

\begin{tabular}{|c|c|}
\hline \multicolumn{2}{|l|}{ Manuscript Number: } \\
\hline Full Title: & $\begin{array}{l}\text { DB Experiment - Comparative study of methods to estimate hydraulic parameters in } \\
\text { the hydraulically undisturbed Opalinus Clay }\end{array}$ \\
\hline Article Type: & Original Paper \\
\hline Corresponding Author: & $\begin{array}{l}\text { Catherine Yu } \\
\text { Institut de Radioprotection et de Surete Nucleaire } \\
\text { FRANCE }\end{array}$ \\
\hline \multicolumn{2}{|l|}{$\begin{array}{l}\text { Corresponding Author Secondary } \\
\text { Information: }\end{array}$} \\
\hline Corresponding Author's Institution: & Institut de Radioprotection et de Surete Nucleaire \\
\hline \multicolumn{2}{|l|}{$\begin{array}{l}\text { Corresponding Author's Secondary } \\
\text { Institution: }\end{array}$} \\
\hline First Author: & Catherine Yu \\
\hline \multicolumn{2}{|l|}{ First Author Secondary Information: } \\
\hline \multirow[t]{8}{*}{ Order of Authors: } & Catherine Yu \\
\hline & Jean-Michel Matray \\
\hline & Julio Gonçalvès \\
\hline & David Jaeggi \\
\hline & Werner Gräsle \\
\hline & Klaus Wieczorek \\
\hline & Tobias Vogt \\
\hline & Erik Sykes \\
\hline \multicolumn{2}{|c|}{ Order of Authors Secondary Information: } \\
\hline \multicolumn{2}{|l|}{ Funding Information: } \\
\hline Abstract: & $\begin{array}{l}\text { The Deep Borehole (DB) experiment gave the opportunity to acquire hydraulic } \\
\text { parameters in a hydraulically undisturbed zone of the Opalinus Clay at the Mont Terri } \\
\text { underground laboratory (Switzerland). Three methods were used to estimate hydraulic } \\
\text { conductivity and specific storage values of the Opalinus Clay formation and its } \\
\text { bounding formations through the } 248 \mathrm{~m} \text { deep borehole BDB-1: application of a } \\
\text { Poiseuille-type law involving petrophysical measurements, spectral analysis of } \\
\text { pressure time series and in situ hydraulic tests. The hydraulic conductivity range in the } \\
\text { OPA given by the first method is } 4 \cdot 10-14 \text { to } 7 \cdot 10-13 \mathrm{~m} \cdot \mathrm{s}-1 \text { with low vertical variability } \\
\text { whereas in situ hydraulic tests suggest higher values up to } 7 \cdot 10-12 \mathrm{~m} \cdot \mathrm{s}-1 \text {. Core } \\
\text { analysis provides economical estimates of the homogeneous matrix hydraulic } \\
\text { properties but do not account for heterogeneities at larger scale such as tectonic } \\
\text { conductive features. Specific storage values obtained by spectral analysis are } \\
\text { consistent and in the order of } 10-6 \mathrm{~m}-1 \text {, while formulations using phase shift and gain } \\
\text { between pore pressure signals were found to be inappropriate to evaluate hydraulic } \\
\text { conductivity in the Opalinus Clay. The values obtained are globally in good agreement } \\
\text { with the ones obtained previously at the rock laboratory. }\end{array}$ \\
\hline Suggested Reviewers: & $\begin{array}{l}\text { Kent Keller } \\
\text { Professor, University of Washington } \\
\text { ckkeller@wsu.edu } \\
\text { Author of Keller, C.K., Van der Kamp, G., Cherry, J.A., 1989. A Multiscale Study of the } \\
\text { Permeability of a Thick Clayey Till. Water Resources Research, Vo. 25, No. 11, 2299- }\end{array}$ \\
\hline
\end{tabular}


Philippe Cosenza

Universite de Poitiers

philippe.cosenza@univ-poitiers.fr 
1 DB Experiment - Comparative study of methods to estimate hydraulic parameters in the

\section{2 hydraulically undisturbed Opalinus Clay}

3

4 Catherine $\mathrm{Yu}^{1{ }^{12}}{ }^{2)}$, Jean-Michel Matray ${ }^{1)}$, Julio Gonçalvès ${ }^{2)}$, David Jaeggi ${ }^{3)}$, Werner Gräsle ${ }^{4)}$,

$5 \quad$ Klaus Wieczorek ${ }^{5)}$, Tobias Vogt ${ }^{(6)}$, Erik Sykes ${ }^{7)}$

6

7

8

9

1) Institut de Radioprotection et de Sûreté Nucléaire, 31 Allée du Général Leclerc, F92260 Fontenay-aux-Roses, France

2) Aix Marseille Université UMR 6635 CEREGE Technopôle Environnement ArboisMéditerranée BP80 F13545 Aix-en-Provence Cedex 4, France

3) Federal Office of Topography swisstopo, Seftigenstrasse 264, 3084 Wabern, Switzerland

4) Federal Institute for Geosciences and Natural Resources (BGR), Stilleweg 2, 30655 Hannover, Germany

5) Global Research for Safety (GRS), Schwertnergasse 1, D-50667 Cologne, Germany

6) National Cooperative for the Disposal of Radioactive Waste (Nagra), Hardstrasse 73, 5430 Wettingen, Switzerland

7) Nuclear Waste Management Organization, 22 St. Clair Ave. E., Toronto, Ontario, Canada

Corresponding author: Catherine Yu. E-mail: catherine.jiyu@irsn.fr 
22 Running title: Hydraulic parameters determination in the Opalinus Clay at the Mont Terri 23 rock laboratory

24 Keywords: Mont Terri rock laboratory, argillaceous formation, Opalinus Clay, hydraulic well 25 tests, Poiseuille-type law, harmonic tidal analysis 


\section{Abstract}

28 The Deep Borehole (DB) experiment gave the opportunity to acquire hydraulic parameters in 29 a hydraulically undisturbed zone of the Opalinus Clay at the Mont Terri underground 30 laboratory (Switzerland). Three methods were used to estimate hydraulic conductivity and 31 specific storage values of the Opalinus Clay formation and its bounding formations through 32 the $248 \mathrm{~m}$ deep borehole BDB-1: application of a Poiseuille-type law involving petrophysical 33 measurements, spectral analysis of pressure time series and in situ hydraulic tests. The 34 hydraulic conductivity range in the OPA given by the first method is $4 \cdot 10^{-14}$ to $7 \cdot 10^{-13} \mathrm{~m} \cdot \mathrm{s}^{-1}$ 35 with low vertical variability whereas in situ hydraulic tests suggest higher values up to $7 \cdot 10^{-12}$ $36 \mathrm{~m} \cdot \mathrm{s}^{-1}$. Core analysis provides economical estimates of the homogeneous matrix hydraulic 37 properties but do not account for heterogeneities at larger scale such as tectonic conductive 38 features. Specific storage values obtained by spectral analysis are consistent and in the order 39 of $10^{-6} \mathrm{~m}^{-1}$, while formulations using phase shift and gain between pore pressure signals were 40 found to be inappropriate to evaluate hydraulic conductivity in the Opalinus Clay. The values 41 obtained are globally in good agreement with the ones obtained previously at the rock 42 laboratory. 


\section{Introduction}

Based on favourable confining properties, such as low permeability, strong retention and selfsealing capacities, clay formations are the preferred host rock option for a deep geological repository of long-lived, intermediate and high level radioactive waste in several countries including France, Belgium and Switzerland. In the latter country, the Opalinus Clay (OPA) has been selected as a potential host rock for a disposal facility (Nagra, 2002) and has been studied at the Mont Terri Underground Rock Laboratory since 1996. The laboratory is located at a depth of ca. $280 \mathrm{~m}$, in the security gallery of the A16 Transjurane motorway, which crosses the Jura Mountains in north-western Switzerland.

The accurate hydraulic characterisation of low permeability formations is of utmost importance to ensure the safety of a geological repository. Hydraulic properties can be estimated by various laboratory and field experiments (Van der Kamp, 2001; Yu et al., 2013), including empirical methods based on the rock matrix properties (Chapuis and Aubertin, 2003), falling head or constant head permeameter tests in laboratory (Boulin et al., 2012), and in situ field tests that rely on measurement of pore pressure or water level changes due to tidal natural loading (Bredehoeft, 1967; Merritt, 2004; Jiang et al., 2013) or artificial application of an hydraulic pressure different from the static formation pressure (Neuzil, 1982; Butler, 1998; Mejías et al., 2009). As these methods are carried out from sub-millimetre to hectometre investigation scales, scale dependency can affect the results (Keller et al., 1989; Neuzil, 1994). 


\section{Geological setting}

The Opalinus Clay at the Mont Terri site is a moderately overconsolidated claystone Aalenian-Toarcian aged stratigraphically, overlain by $800 \mathrm{~m}$ of Middle to Late Jurassic limestones, marls and shales, and underlain by $400 \mathrm{~m}$ of Early Jurassic to Triassic marls and limestones, dolomites and anhydrites (Fig. 1). The true lithological thickness of the clayey formation is $130 \mathrm{~m}$ and its apparent thickness in the area reaches $160 \mathrm{~m}$ due to thrusting and faulting. A period of marine regression occurred between 100 and $25 \mathrm{Ma}$, leading to a subaerially exposure of the top of the Malm limestone. Starting about $40 \mathrm{Ma}$, the rifting of the Rhine Graben affected Northern Switzerland, resulting in considerable uplift of the area in the mid-Tertiary and followed by down-warping and burial under late Tertiary sediments. The Opalinus Clay reached a burial depth of $1000 \mathrm{~m}$ and $1700 \mathrm{~m}$ respectively during these two phases of subsidence. Late Alpine folding during the late Miocene to Pliocene (about 10 to 2 Ma) formed the Folded Jura. Erosion exposed the core of the Mont Terri anticline towards 2.5 Ma, and allowed fresh water infiltration to the Middle Jurassic limestones. Similarly, infiltration to the Early Jurassic limestones would have started in the Quaternary, around 350 thousand years ago (Pearson et al., 2003).

Three main facies were identified within the Opalinus Clay (Blaesi et al., 1991): a shaly facies in the lower part of the sequence, a thin carbonate-rich sandy facies in the middle part of the formation, and a sandy facies interstratified with shaly facies in the upper sequence. The shaly facies mineral composition includes $27-78 \%$ of clay minerals (illite, chlorite, kaolinite and illite-smectite mixed layers), 4-29\% of carbonates, $10-32 \%$ of quartz, and accessory feldspars, pyrite and organic matter (Bossart and Thury, 2008).

7 Several minor tectonic faults and a larger fault zone called "Main Fault" can be observed in 8 the Opalinus Clay (Nussbaum et al., 2001). Nagra's investigations in deep boreholes at 
hydraulically similar to the undeformed matrix (Johns et al., 1994; Gautschi, 2001a). Based on permeameter tests and in situ packer tests, hydraulic conductivity values in tectonically disturbed zones are in the range of $2 \cdot 10^{-14}$ to $2 \cdot 10^{-12} \mathrm{~m} \mathrm{~s}^{-1}$, and specific storage ranges from $2 \cdot 10^{-7}$ to $1.7 \cdot 10^{-4} \mathrm{~m}^{-1}$ (Marschall et al., 2005).

\section{BDB-1 Deep Borehole}

The Deep Borehole experiment (DB) aims at evaluating the hydrogeological properties and processes of undisturbed Opalinus Clay at the Mont Terri Underground Rock Laboratory. For the first time in this laboratory, a $247.5 \mathrm{~m}$ long $45^{\circ}$ downward inclined borehole has been drilled through the Opalinus Clay and the bounding formations. The stratigraphic sequence crossed by the borehole is presented in Figure $2 \mathrm{a}$ and is described in detail in Jaeggi et al (2017, this issue). The borehole was entirely cored for stratigraphic, petrophysic, mineralogical and geochemical studies. The OPA section was drilled with air as drilling fluid. 102 Drilling was immediately followed by the installation of a multipacker system (Fierz and 103 Rösli, 2014) consisting in five double packer measuring intervals and an interval port within 104 the Opalinus Clay, a single packer in the Staffelegg formation at the bottom of the borehole, 105 and a further double packer interval isolating the lowermost zone of the Passwang Formation (Fig. $2 b$ and c). Intervals were equipped with sensors that enable long term monitoring of 107 pressure and temperature (Table 1). Pressure sensors are located at the surface and connected 108 by stainless steel lines to the interval fluids, whereas temperature sensors are located 109 downhole inside the intervals. 
5

6

8

0

1

\subsection{Petrophysical model}

Assuming a plane-parallel geometry, the intrinsic permeability can be computed across an argillaceous formation using a semi-empirical Poiseuille-type law (Kostek et al. 1992; Pape et al., 1999; Tremosa, 2010):

$$
k=\frac{b^{2}}{3 F}
$$

115 where $k$ is the intrinsic permeability $\left[\mathrm{m}^{2}\right], b$ is the half-pore size [m] and $F$ is the formation 116 factor [-], which accounts for the tortuosity of the porous media and can be determined using 117 the Archie's law (Archie, 1952):

$$
F=\omega^{-m}
$$

118 where $\omega$ is the porosity [-] and $m$ is the cementation factor. The formation factor can also be 119 related to diffusion parameters (Boving and Grathwohl, 2001; Van Loon and Mibus, 2015):

$$
F=\frac{D_{w}}{D_{e}}
$$

120 where $D_{w}$ is the diffusion coefficient in pure water $\left[\mathrm{m}^{2} \mathrm{~s}^{-1}\right]$ and $D_{e}$ is the effective diffusion 121 coefficient $\left[\mathrm{m}^{2} \mathrm{~s}^{-1}\right]$.

122 The half-pore size can be computed from petrophysical parameters according to the following 123 relation based on a mass balance equation (Neuzil, 2000; Altinier, 2006):

$$
b=\frac{\omega}{(1-\omega) \rho_{s} A_{s}}
$$

124 where $b$ is the half-pore size [m], $\omega$ is the porosity [-], $\rho_{s}$ is the grain density $\left[\mathrm{g} \mathrm{m}^{-3}\right]$ and $A_{s}$ is 125 the specific surface area $\left[\mathrm{m}^{2} \mathrm{~g}^{-1}\right]$.

126 Intrinsic permeability and hydraulic conductivity are linked according to: 


$$
K=\frac{k \rho_{f} g}{\mu_{f}}
$$

127 where $K$ is the hydraulic conductivity $\left[\mathrm{m}^{-1} \mathrm{~s}^{-1}\right], \rho_{f}$ is the fluid density $\left[\mathrm{kg} \mathrm{m}{ }^{-3}\right], g$ is the gravity 128 acceleration $\left[\mathrm{m} \mathrm{s}^{-2}\right]$ and $\mu_{f}$ is the fluid dynamic viscosity $[\mathrm{Pa} \mathrm{s}]$.

129 Fluid dynamic viscosity was estimated according to Mercer et al. (1975):

$$
\mu_{f}=\left(5.38+3.8 A-0.26 A^{2}\right) \cdot 10^{-3}
$$

with

$$
A=\frac{T-150}{100}
$$

130 where $\mu_{f}$ is the fluid dynamic viscosity $[\mathrm{Pa} \mathrm{s}]$ and $T$ is the temperature $\left[{ }^{\circ} \mathrm{C}\right]$.

131 The Unesco equation of state (Unesco, 1981) was used to determine the fluid density as a 132 function of salinity, temperature and pressure.

133 Determination of petrophysical parameters were performed in laboratory on representative 134 element volume samples taken from the central part of BDB-1 drillcores. Porosity and water 135 contents were determined by weighing before and after oven-drying at $105^{\circ} \mathrm{C}$ until mass 136 stabilisation. Density and degree of saturation were calculated based on Archimede's 137 principle after sample immersion into kerdane following the experimental protocol first 138 proposed by Monnier et al. (1973) and later adapted by Matray et al. (2007) for argillite 139 samples. Grain density was evaluated using a helium pycnometer (Micromeritics® AccuPyc 140 II 1340) on oven-dried samples and also recalculated from results of X-Ray diffraction 141 measurements on bulk samples.

1424.2 In situ hydraulic testing experiments

143 Hydraulic in situ testing in boreholes, also referred as well testing, is the most common 144 method used in groundwater and oil industries to acquire the hydraulic properties of 145 geological formations. Pulse withdrawal tests and constant rate withdrawal tests were 
146 conducted in BDB-1 borehole, from March $11^{\text {th }}$ to November $16^{\text {th }} 2015$. During a withdrawal 147 pulse test, pressure is lowered abruptly by opening and closing the downhole shut-in valve (Bredehoeft and Papadopoulos, 1980; Neuzil, 1982). These tests are preferred as initial phase because they give an immediate measurement of the system compressibility and generally require shorter time frame than pumping tests. Given its quick hydraulic response, performing more pulse tests on interval 1 (Staffelegg Formation, Fig. 2b) was possible, whereas two pulse tests were carried out on each of the other intervals.

153 Constant rate withdrawal test parameters such as flow rate and flow duration must be chosen 154 with caution. In low permeability media, high flow rates can lead to desaturation of the 155 measuring intervals and extreme drops in pressure. Therefore, a flowmeter able to sustain a 156 very low pumping rate of $0.3 \mathrm{~g} \mathrm{~h}^{-1}$ for several days (Bronkhorst ${ }^{\mathbb{R}} \mu$-flow L01) was used to test 157 intervals 2 to 7 (Fig. 2b), for which the hydraulic responses to pulse testing were the slowest. 158 Interval 1 was tested with a higher flow rate of $5 \mathrm{ml} \mathrm{min}^{-1}$ using a Bronkhorst ${ }^{\circledR}$ Liqui-Flow 159 L10. Experimental setups for both kind of tests and associated hydraulic responses are 160 respectively reported in Figure 3 and 4. Flowmeter failed during the testing of intervals 2 and 1616 and approximatively two months of pressure recovery were required before performing a 162 second test on these test chambers.

163 Hydraulic test data were analysed using the well-test interpretation program nSIGHTS, which 164 was developed by INTERA for Sandia National Laboratories. The code is based on Barker's 165 equation (1988), which describes flow in an n-dimensional space, and does not restrict to 166 integer dimensions. Uncertainties associated with the fitting parameters are evaluated by 167 performing random perturbation analyses. Plausibility ranges for various parameters were 168 defined prior to the parameter optimisation procedure (Table 2). During the inverse parameter 169 estimation, nSIGHTS provides best-fit results within these pre-defined ranges. Uncertainties 
170 associated with the fitting parameters are evaluated by performing random perturbation 171 analyses (not detailed in this paper).

1724.3 Tidal analysis on pore pressure time series

173 Rotational and gravitational forces exerted by the sun and the moon on the Earth induce 174 latitudinal and longitudinal strains within the solid matrix and cause deformations with two 175 dominant periods: diurnal and semi-diurnal. The tidal gravitational potential can be resolved 176 into a finite set of tidal components described as harmonics, which are sinusoidal functions of 177 given amplitude and frequency (Doodson and Warburg, 1941; Cutillo and Bredehoeft, 2011). 178 Five main components account for about $95 \%$ of the tidal potential: the $\mathrm{M}_{2}$ and $\mathrm{N}_{2}$ 179 semidiurnal lunar tides, the $\mathrm{S}_{2}$ semidiurnal solar tide, the $\mathrm{O}_{1}$ diurnal lunar tide, and the $\mathrm{K}_{1}$ 180 diurnal lunar-solar tide.

181 Seasonal or climatic variations, anthropogenic activities and tidal forces induce hydraulic 182 pressure changes in geological formations. The amplitude of the pressure response depends 183 on the poroelastic response of the aquifer matrix. Pressure signal can therefore be analysed to 184 determine hydrogeological properties, such as specific storage, effective porosity and 185 hydraulic conductivity. The models used in this work are based on Terzaghi's (1936) effective 186 stress concept, which assumes a constant total stress distributed between grains and fluid 187 effective stress. Bredehoeft (1967) related tidal strain to specific storage:

$$
S_{s}=\frac{|\Delta \varepsilon|}{|\Delta h|}
$$

188 where $S_{s}$ is the specific storage $\left[\mathrm{m}^{-1}\right],|\Delta \varepsilon|$ is the amplitude of volumetric strain fluctuation 189 fixed at $2 \cdot 10^{-8}$ for the $\mathrm{M}_{2}$ tide (Melchior, 1978), and $|\Delta h|$ is the amplitude of relative pressure 190 head fluctuations [m].

191 Jacob's (1940) formula was used to compute the porosity: 


$$
\omega=\frac{E_{W} S_{S} B}{\rho_{f} g}
$$

192 where $\omega$ correspond to the porosity [-], $E_{W}$ is the stiffness modulus of water, equal to 2.05 $193 \mathrm{GPa}, S_{\mathrm{s}}$ is the specific storage $\left[\mathrm{m}^{-1}\right], B$ is the barometric efficiency [-], which reflects the 194 elastic response of the system, $\rho_{f}$ is the fluid density, and $g$ is the gravity acceleration equal to $1959.81 \mathrm{~m} \mathrm{~s}^{-2}$.

196 Hydraulic conductivity was estimated with formulations using the $\mathrm{M}_{2}$ harmonic amplitude 197 and phase shift (Boldt-Leppin and Hendry, 2003; Timms and Acworth, 2005), measured at 198 two depths, $z_{l}$ and $z_{2}[\mathrm{~m}]$ :

$$
\begin{gathered}
K_{v}^{A m p}\left(f_{M_{2}}\right)=S_{S}\left(f_{M_{2}}\right) \frac{\pi\left(z_{1}-z_{2}\right)^{2}}{\left(f_{M_{2}}\right)^{-1}}\left[\ln \left(\frac{A_{z_{1}}\left(f_{M_{2}}\right)}{A_{z_{2}}\left(f_{M_{2}}\right)}\right)\right]^{-2} \\
K_{v}^{\Delta \varphi}\left(f_{M_{2}}\right)=S_{S}\left(f_{M_{2}}\right) \frac{\pi}{\left(f_{M_{2}}\right)^{-1}}\left[\frac{\left(z_{1}-z_{2}\right)}{\Delta \varphi\left(f_{M_{2}}\right)}\right]^{2}
\end{gathered}
$$

199 where $K_{v}^{A m p}$ is the "amplitude effective hydraulic conductivity", $A_{z l}$ and $A_{z 2}[\mathrm{kPa}]$, are the $\mathrm{M}_{2}$ 200 earth tide amplitude associated to the sensors, $S_{s}\left[\mathrm{~m}^{-1}\right]$ is the arithmetic mean of the effective 201 specific storage coefficients obtained individually for the two sensors, $f_{M 2}\left[\mathrm{~s}^{-1}\right]$ is the 202 frequency of the $\mathrm{M}_{2}$ earth tide equal to $2.236 \cdot 10^{-5} \mathrm{~Hz}, K_{v}{ }^{4} \varphi\left[\mathrm{m} \mathrm{s}^{-1}\right]$ is the "phase effective 203 hydraulic conductivity", and $\Delta \varphi$ [rad] is the spectral phase shift between the sensors.

204 Spectral analysis of BDB-1 borehole pressure dataset was performed using the Multi205 Statistical Analysis Tool (MuSTAT), jointly developed by the Institut de Radioprotection et 206 de Sûreté Nucléaire and the Institut National Polytechnique de Toulouse (Fatmi et al., 2008; 207 Ababou et al, 2012; Bailly et al., 2014). Consisting in a Python code associated with 208 toolboxes programmed in Matlab, the package provides automatic features: a) preprocessing of time series, that enables the detection of time gaps and spurious values, as well as data 
reconstruction by autoregressive first order process; b) processing of a single time series; c)

211 cross-analysis of two time series.

\section{Results at various scales of investigation}

213 5.1 Sub-millimeter to centimeter scale

\section{5.1.1 Petrophysical parameters}

215 The petrophysical parameters necessary for the computation of intrinsic permeability are

217 The water accessible porosity is $13.0 \%$ in the Opalinus Clay, with a lower porosity of $12.0 \%$ 218 in the sandy facies compared to the shaly facies, which exhibit a mean porosity of $13.5 \%$. 219 These values are lower than the mean value of $18 \%$ suggested by previous studies performed 220 at the Mont Terri tunnel level. The Passwang Formation presents slightly lower porosity 221 values ranging between $8.1 \%$ and $14.6 \%$ with a mean value of $12.2 \%$. The Hauptrogenstein 222 is characterized by the lowest porosity with a mean value of $3.9 \%$.

223 Grain densities obtained by helium pycnometry have a mean value of $2.74 \mathrm{~g} \mathrm{~cm}^{-3}$ in the 224 Opalinus Clay overlying formations and of $2.72 \mathrm{~g} \mathrm{~cm}^{-3}$ in the argillaceous layer. The lowest 225 grain densities are found in the bituminous Rietheim Member of the Staffelegg Formation 226 (see Fig. 1a), ranging between 2.3 and $2.4 \mathrm{~g} \mathrm{~cm}^{-3}$. These low values are probably linked to the 227 presence of organic matter.

228 The Passwang formation, which directly overlays the Opalinus Clay, does not reveal clear 229 petrophysical discrepancies with the clay formation except for the specific surface area. This 230 parameter has an average value of $13 \mathrm{~m}^{2} \mathrm{~g}^{-1}$ in the carbonated section of the borehole and 231 shows significant fluctuations linked to the marly composition of the Passwang formation. A 232 higher mean value of $29 \mathrm{~m}^{2} \mathrm{~g}^{-1}$ characterises the Opalinus Clay. 
233 The Opalinus clay is also characterised by a low pore size. Analyses of nitrogen adsorption 234 and desorption isotherms show that $70 \%$ to $93 \%$ of the connected porous network is constituted of mesopores (pore diameter between 2 and $50 \mathrm{~nm}$ ), with a mean size of $13 \mathrm{~nm}$.

238 Ranging between 1.3 and 5.4 (Horseman et al, 1996), the cementation factor was estimated to 239 be close to 2 for compacted and deeply buried sediments (Ullman and Aller, 1982; Tremosa, 240 2010). Van Loon et al (2003b) related the effective diffusion coefficient of tritium measured 241 in the Opalinus Clay to its porosity using a cementation factor of 2.5 .

255 The corresponding hydraulic conductivity profiles are presented (Fig. 6b) and show similar 256 trends compared with the intrinsic permeability profiles. The hydraulic conductivity obtained

\subsubsection{Intrinsic permeability and hydraulic conductivity}

The intrinsic permeability profiles (Fig. 6a) show a low vertical variability through the Opalinus Clay, where it ranges between $5.79 \cdot 10^{-21}$ and $6.14 \cdot 10^{-20} \mathrm{~m}^{2}$ if a cementation factor varying between 2 and 2.5 is taken. For a cementation factor of 2.5 , the mean intrinsic permeability is $7.7 \cdot 10^{-21} \mathrm{~m}^{2}$ for the Opalinus Clay shaly facies and $7.9 \cdot 10^{-21} \mathrm{~m}^{2}$ for its sandy facies. These values are in good agreement with the range of $1 \cdot 10^{-21}$ and $6 \cdot 10^{-20} \mathrm{~m}^{2}$ obtained by gas injection experiments performed at the Mont Terri laboratory (Marschall et al., 2005). Based on the same cementation factor, difference can be seen in the carbonate-rich sandy facies, where values are about three times higher than in the shaly and the sandy facies. With a higher exponent $m=3$, the resulting intrinsic permeability has a mean value of $7.6 \cdot 10^{-21} \mathrm{~m}^{2}$ and no clear distinction arises between the different facies. The intrinsic permeability values computed in the Passwang formation and the Staffelegg formation are much more heterogeneous and vary between $1.5 \cdot 10^{-21}$ and $5.8 \cdot 10^{-20} \mathrm{~m}^{2}$. 
257 for the Opalinus clay ranges between $5.8 \cdot 10^{-14}$ and $5.8 \cdot 10^{-13} \mathrm{~m} \mathrm{~s}^{-1}$ for a cementation factor varying between 2 and 2.5. For a cementation factor of 2.5 , the formation is characterised by a mean hydraulic conductivity of $8.3 \cdot 10^{-14} \mathrm{~m} \mathrm{~s}^{-1}$. No clear discrepancy between the shaly facies and the sandy facies is revealed, with respective mean values of $7.3 \cdot 10^{-14}$ and $6.9 \cdot 10^{-14} \mathrm{~m} \mathrm{~s}^{-1}$. These values are consistent with the range of $2 \cdot 10^{-14}$ to $1 \cdot 10^{-12} \mathrm{~m} \mathrm{~s}^{-1}$ reported in previous studies (Bossart and Thury, 2008). The Passwang formation and the Staffelegg formation present a various range of hydraulic conductivities between $1.6 \cdot 10^{-14}$ and $6.1 \cdot 10^{-13} \mathrm{~m} \mathrm{~s}^{-1}$.

5.2 Decimeter to meter scale: in situ hydraulic tests results

Pore pressure should be fully recovered from artificial disturbance induced by the installation procedure (e.g. drilling, logging, equipment installation) before starting a hydraulic test.Steady state was considered to be reached when the tidal components were detected on all pore pressure time series acquired in BDB-1 borehole, which indicate that the system is fully pressurised and saturated (see section 5.3.1).

The observed compressibility of the test zone $\left(C_{t z}\right)$ was deduced from pulse tests and computed according to:

$$
C_{t z}=\frac{1}{V_{t z}} \frac{d V}{d P}
$$

where $V_{t z}\left[\mathrm{~m}^{3}\right]$ is the shut-in volume, $d V\left[\mathrm{~m}^{3}\right]$ is the withdrawn volume and $d P[\mathrm{~Pa}]$ is the pressure variation. Test zone compressibility in BDB-1 borehole varies $9.1 \cdot 10^{-10} \mathrm{~Pa}^{-1}$ and $2.4 \cdot 10^{-9} \mathrm{~Pa}^{-1}$ (Fig. 7), approximately up to a factor of 5 larger than water compressibility, which is equal to $4.8 \cdot 10^{-10} \mathrm{~Pa}^{-1}$ at $10{ }^{\circ} \mathrm{C}$ (Kell, 1975). The discrepancy can be attributed to the mechanical compliance of the equipment. Semi-logarithmic plots presented in Figure 8 give a qualitative comparison of the hydraulic behaviours characterising the different tested intervals. Degree of pore pressure dissipation $(U)$ and normalised drawdown pressure $\left(U_{n o r m}\right)$ are respectively defined by the following equations: 


$$
\begin{gathered}
U=\frac{U_{t}-U_{0}}{U_{\min }-U_{0}} \\
U_{\text {norm }}=\frac{U_{t}-U_{\min }}{U_{0}-U_{\min }}
\end{gathered}
$$

279 where $U_{t}[\mathrm{kPa}]$ is the pore pressure at time $t, U_{0}[\mathrm{kPa}]$ is the hydrostatic pore pressure in situ and $U_{\min }$ $280[\mathrm{kPa}]$ is the pore pressure reached after pulse application or at the end of the pumping phase.

281 Discrepancies in the degree of dissipation can be observed between tests performed on a same 282 interval (Fig. 8a). Constant rate withdrawal tests were carried out using the same flow rate of $2830.3 \mathrm{~g} \mathrm{~h}^{-1}$ for different durations. To compare the evolution of pore pressures in the measuring 284 intervals during pumping phase, $P_{\min }$ was taken to correspond to the shortest pumping 285 duration in the calculation of $U_{\text {norm. }}$. If specific storage is assumed homogeneous through the 286 Opalinus Clay, the order from left to right on Figure $8 \mathrm{~b}$ gives an indication of decreasing 287 permeability.

288 The application of a composite model, which takes into account a damaged skin zone, was 289 required for most of the test numerical interpretations. Taking as an example the first pulse 290 test carried out on BDB-1 Interval 2, Figure 9 shows a comparison of the residuals (measured 291 value minus simulated value) to that of a normal distribution, using a homogeneous model 292 and a composite one. The homogeneous model appears to be unsatisfactory because the 293 residuals are not normally distributed, which indicates the presence of a systematic error.

294 Pulse tests and constant rate pumping tests results are respectively compiled in Table 3. Pulse 295 testing revealed the highest hydraulic conductivity values in the Staffelegg Formation 296 (Interval 1, see Fig. 2b) with best fit values ranging from $2.1 \cdot 10^{-10}$ to $5.9 \cdot 10^{-10} \mathrm{~m} \mathrm{~s}^{-1}$. Located 297 in the basal shaly facies of Opalinus clay (Interval 2), the bottom part of the main fault zone is 298 characterised by conductivity values from $3.1 \cdot 10^{-12}$ to $7.3 \cdot 10^{-12} \mathrm{~m} \mathrm{~s}^{-1}$ and do not differ from the upper shaly facies represented by Interval 4 (Fig. 10) and 5, whose best estimates are up to 
$4.2 \cdot 10^{-12} \mathrm{~m} \mathrm{~s}^{-1}$. The lowest values are found in the sandy facies (Interval 6 , best fit values up to $2.7 \cdot 10^{-13} \mathrm{~m} \mathrm{~s}^{-1}$ ), and the carbonate-rich sandy facies (Interval 3, best fit values up to $5.1 \cdot 10^{-}$ ${ }^{13} \mathrm{~m} \mathrm{~s}^{-1}$ ). The basal part of the Passwang formation, represented by Interval 7, shows similar hydraulic conductivity values to Opalinus clay $\left(5.8 \cdot 10^{-13}\right.$ to $\left.1.4 \cdot 10^{-12} \mathrm{~m} \mathrm{~s}^{-1}\right)$.

The analyses results of the constant flowrate withdrawal tests are quite consistent with those obtained from pulse tests. Indeed, a similar trend can be observed with slightly higher permeability values in the shaly facies than in the sandy facies of Opalinus Clay.

Specific storage and flow dimension estimates are highly variable. One issue with single well hydraulic testing is that the volume of tested rock is limited to the immediate vicinity of the well.

$310 \quad 5.3$ Hectometer scale: tidal analysis

\section{5.3.1 Tidal identification in BDB-1 pore pressure series}

312 Detection of tidal components was performed on the pore pressure time series monitored by 313 the sensors placed in BDB-1 borehole, with an acquisition time step set at 15 minutes. The 314 four largest amplitude tidal components, $\mathrm{O}_{1}, \mathrm{~K}_{1}, \mathrm{~S}_{2}$ and $\mathrm{M}_{2}$ appear on all processed signals at 315 the exact expected frequencies for time series between September $1^{\text {st }} 2014$ and March $10^{\text {th }}$ 3162015 (Fig. 11).

317 The form ratio is defined as the sum of the two main diurnal component amplitudes, $\mathrm{K}_{1}$ and $318 \mathrm{O}_{1}$, divided by the sum of the two main semi-diurnal component amplitudes, $\mathrm{M}_{2}$ and $\mathrm{S}_{2}$ 319 (Wiegel, 1964). Tidal deformation through the Opalinus Clay at Mont Terri is characterized 320 by a form ratio varying between 0.84 and 1.35 , which indicates a mixed, mainly semi-diurnal tide (Table 4). The maximum value is found in the interval located in the Passwang formation, for which the diurnal components have slightly higher amplitudes than the semi-diurnal ones. Except for this interval, the $\mathrm{M}_{2}$ tide presents the highest amplitude among the four major tides. 


\subsubsection{Hydraulic parameters computation}

The results of specific storage coefficient computation are given in Table 5. Specific storage values are ranging between $1.08 \cdot 10^{-6}$ and $1.56 \cdot 10^{-6} \mathrm{~m}^{-1}$ in the Opalinus Clay and are higher for the adjacent formations $\left(2.35 \cdot 10^{-6} \mathrm{~m}^{-1}\right.$ for the Lower Dogger limestone and $3.08 \cdot 10^{-6} \mathrm{~m}^{-1}$ for the Staffelegg Formation). These estimates are consistent with the range given in the literature, deduced from in situ packer tests and permeameter tests for the Opalinus Clay shaly facies: 348 in the BCD-3 borehole located at the Mont Terri tunnel level. They obtained hydraulic between $1 \cdot 10^{-7}$ and $1 \cdot 10^{-4} \mathrm{~m}^{-1}$, with a best estimate at $2 \cdot 10^{-6} \mathrm{~m}^{-1}$ (Bossart and Thury, 2008).

Effective dynamic porosity values obtained using the $\mathrm{M}_{2}$ tide (Table 6) are globally in well agreement with those obtained from petrophysical measurements. Indeed, coherent values between $8 \%$ and $24 \%$ are obtained by cross-analyses of measuring intervals located in the Opalinus Clay. Statistical analysis carried out in previous studies on Mont Terri samples (Fatmi, 2009, Bailly and Matray, 2015) revealed very low range values between $1 \%$ and 4\% at the tunnel level. These unexplained low values could be related to the hydraulically disturbed state of the studied area and desaturation phenomena.

Hydraulic conductivity values obtained in the saturated part of the claystone by cross-analysis (Table 6) are much higher than those obtained by other techniques. Indeed, high conductivities ranging between $5.7 \cdot 10^{-5} \mathrm{~m} \cdot \mathrm{s}^{-1}$ and $1.4 \cdot 10^{-7} \mathrm{~m} \cdot \mathrm{s}^{-1}$ are found in the Opalinus Clay. These values are 6 to 8 orders of magnitude higher than the range expected from literature data, suggesting that the method is not appropriate for this formation. Discrepancies up to three orders of magnitude between laboratory hydraulic conductivity results and tidal analysis results were also reported by Boldt-Leppin et al. (2003) who studied the King site claystone formation (Canada). These discrepancies were explained by scale factor effects and the presence of fractured area.

Bailly and Matray (2015) performed statistical analysis on pore pressure time series acquired 
349 conductivities ranging between $1.9 \cdot 10^{-10}$ and $7.5 \cdot 10^{-11} \mathrm{~m} \cdot \mathrm{s}^{-1}$ in the unsaturated part of the

Opalinus clay by applying the same method on the $\mathrm{S}_{1}$ solar diurnal tide. The $\mathrm{M}_{2}$ tide was not found in the studied pore pressure time series due to suction conditions associated to the rock laboratory level. The study also suggested that the structures observed in this borehole were hydraulically conductive, meaning that the Opalinus clay true permeability should be even lower than the range given by tidal analysis.

\section{Discussion}

6.1 Comparability of laboratory tests and in situ tests results

Reliable estimates of permeability and specific storage that describe the bulk hydraulic behaviour are needed for the evaluation of contaminant leakage in geological formations. Linking the results of laboratory tests to bulk characteristics at the regional scale is not straightforward and the meaning of measured values has to be interpreted. Sedimentary rocks are generally associated with anisotropic properties such as permeability, diffusion coefficient and mechanical features. In the Opalinus Clay, which is a overconsolidated clay, a moderate permeability anisotropy ratio of 5.5 was estimated based on laboratory permeameter tests (Münoz et al., 2003, Croisé et al., 2004, Fernàndez-Garcia et al., 2007).

The petrophysical model is based on a conceptual parallel plane geometry which would be associated to a flow orientation parallel to bedding planes. Since BDB-1 borehole was drilled perpendicular to bedding plane, the main solicited direction for fluid flow during hydraulic testing is also parallel to stratification. For its part, tidal analysis is mainly based on gravitational forces that propagate radially from the center of the Earth and should result, given the setting of the Mont Terri anticline, in composite values of parallel and perpendicular to bedding permeabilities. 
372 Although the petrophysical model may be unsuited to carbonated formations, calculation was 373 also performed on the Passwang formation and the Staffelegg formation, which shows similar 374 6 petrophysical parameters. Another questionable point is the use of a constant value for the Archie's exponent since this parameter depends on the nature of the porous medium. Consequentely, adapted values should be taken according to the evolution of rock facies along 377 the stratigraphic sequence.

378 Fitting the cementation factor by comparing petrophysical results and estimates from 379 hydraulic tests can be debatable. Indeed, the volume of solicited rock is higher in the latter 380 case and takes greater account of formation heterogeneities and local open fractures. This 381 point is clearly illustrated by the discrepancies observed for the Staffelegg formation, in 382 which many fractures were evidenced by drillcore mapping. Indeed, petrophysical 383 measurements on centimetre-scale samples do not take into account these hydraulically 384 conductive structures and underestimate the values of bulk properties.

385 Archie's law is rigorously an empirical relationship that links the electrical resistivity of 386 saturated clay-free rocks and their porosity. However, an analogy can be made between the 387 electrical potential and the concentration gradient. It has been shown that effective diffusion 388 coefficient could be predicted by this relationship in a variety of clay and shales with a 389 cementation factor ranging between 2 and 3 (Boving and Grathwohl, 2001; Van Loon et al., 390 2003b; Mazurek et al., 2009). Best fit values of hydraulic conductivity obtained from 391 hydraulic testing are generally higher that those computed with the petrophysical law (Fig. 392 12a). Hydraulic conductivities higher than $10^{-12} \mathrm{~m} \mathrm{~s}^{-1}$ found in the Opalinus Clay shaly facies 393 would be associated to illogical values of cementation factor inferior to 1.3 , which was given 394 for clean unconsolidated sand packs by Archie (1942).

395 Whether it be for pulse or constant withdrawal tests, the numerical interpretation of hydraulic tests suggests rather wide and unrealistic ranges of uncertainties for hydraulic conductivity 
and specific storage. Covering several orders of magnitude and not tightly around the best estimates (Table 3), these uncertainties are probably linked to the large number of fitted parameters. Tidal analysis may be more representative than single well hydraulic testing for specific storage estimation (Fig. 12b), since the tidal deformation is applied to the entire rockmass.

$402 \quad 6.2$ Consistency with previous results

403 Numerous in situ and laboratory investigations have been carried out at the Mont Terri rock 404 laboratory to characterize the hydraulic properties of the Opalinus Clay. Laboratory 405 permeameter tests revealed conductivity values ranging from 6 to $12 \cdot 10^{-14} \mathrm{~m} \mathrm{~s}^{-1}$ with high 406 associated storage coefficient of $4.8 \cdot 10^{-4} \mathrm{~m}^{-1}$ (Croisé et al., 2004). Figure 13 shows a 407 compilation of permeability results obtained from packer tests (pulse, constant head and 408 constant rate) performed previously at the Mont Terri site (AF Consult, 2012), along with data 409 collected in BDB-1 borehole. Tests were mainly performed in boreholes oblique or normal to 410 bedding drilled in area unaffected by the excavation damaged zone of the tunnel. Previous 411 permeability values measured at the rock laboratory level range from $1.5 \cdot 10^{-14}$ to $1.1 \cdot 10^{-9} \mathrm{~m} \mathrm{~s}^{-}$ $412{ }^{1}$ with $55 \%$ of the values in the order of $10^{-13} \mathrm{~m} \mathrm{~s}^{-1}$. The best fit values obtained from BDB-1 413 hydraulic testing fall virtually in the expected range with higher values in the order of $10^{-12} \mathrm{~m}$ $414 \mathrm{~s}^{-1}$ characterising the Opalinus Clay shaly facies.

415 Specific storage coefficients obtained by tidal analysis are rather homogeneous within the 416 Opalinus Clay with values in the order of $10^{-6} \mathrm{~m}^{-1}$, which are comparable to the range of $2 \cdot 10^{-}$ $417{ }^{6}$ to $5 \cdot 10^{-6} \mathrm{~m}^{-1}$ found by Bailly and Matray (2015).

418 No significant correlation between the hydraulic conductivity and the different lithological 419 facies was highlighted by Croisé et al (2004), Nussbaum and Bossart (2004) and AF Consult (2012) due to a lack of data from the sandy facies. Although best fit values obtained from 
BDB-1 borehole indicate higher values in the shaly facies, uncertainty ranges make it difficult

to conclude on a possible contrast. Sandstone lenses embedded in clay rich strata could affect

the hydraulic behaviour of the unit not necessarily against its barrier function. Indeed, Opalinus Clay sandy layers are better cemented and display lower porosities (Fig. 5a). Microscopic observations in the sandy facies revealed precipitation of authigenic quartz, carbonates and kaolinite (Peters et al., 2011). On the other hand, porosity values measured in BDB-1 borehole are globally lower than those obtained at the rock laboratory tunnel level and may reflect the deconfinement and relaxation of stresses occurring at the latter location.

The Main fault that intersects the laboratory does not impact the barrier function of the Opalinus Clay. Indeed, the sealing of fault planes by calcite shear fibres and clay minerals induce small effect of tectonic deformation on the hydraulic properties of the Opalinus Clay 432 (Nussbaum et al., 2011). This observation is supported by the consistency between the 433 hydraulic tests performed in the intact shaly facies and those carried out in the interval 434 crossing the fault zone. Similarly, no contrast can be identified on the different profiles 435 obtained with the petrophysical model.

\section{Conclusions}

437 The Deep Borehole experiment enabled the acquisition of data in a fresh borehole penetrating 438 the entire hydraulically undisturbed Opalinus Clay at Mont Terri. Therefore, the presented 439 results are unique, because other hydraulic data at Mont Terri are or might be influenced by 440 tunneling and experimental activities. Three methods with different investigation volumes 441 were carried out and compared.

442 A model that links intrinsic permeability to petrophysical parameters gives values in the order 443 of $10^{-20} \mathrm{~m}^{2}$, corresponding to hydraulic conductivities in the order of $10^{-13} \mathrm{~m} \cdot \mathrm{s}^{-1}$. Tidal 444 analysis revealed itself not to be an appropriate method to compute hydraulic conductivity in 
our study, giving values overestimated of several orders of magnitudes. However, this approach gives reasonable values for specific storage and effective porosity. As a third method, in situ hydraulic testing was performed using the multipacker system installed in BDB-1 borehole. Hydraulic conductivity values obtained by numerical inversion from pulse tests are consistent with those deduced from constant rate withdrawal tests, and suggest a vertical variability across the formation possibly due to local variations of the matrix structure, composition and cementation, or the presence of fractures. In conclusion, the hydraulic conductivity values of the DB Experiment agree well with previous hydraulic testing results performed in the hydraulically disturbed Opalinus Clay around the Mont Terri Underground 454 Rock Laboratory. Therefore, future hydraulic testing in the laboratory outside the excavated 455 damaged zone can be rated as comparable to undisturbed conditions. However, our results 456 clearly show higher values (in the order of $10^{-12} \mathrm{~m} \mathrm{~s}^{-1}$ ) for the Opalinus Clay shaly facies than 457 its sandy facies (in the order of $10^{-13} \mathrm{~m} \mathrm{~s}^{-1}$ ), which is consistent with microscopic observations

(Peter et al., 2011). Further laboratory experiments using Hassler cells will be performed to characterise the Opalinus Clay permeability anisotropy.

Petrophysical analysis of drillcores and time-series analyses are complementary to hydraulic testing and can provide economical estimates of hydraulic parameters. These techniques involve different volumes of investigation. Core analysis, as well as laboratory permeameter tests, give the homogeneous matrix hydraulic properties but do not account for larger scale heterogeneities such as sedimentary and tectonic features. Moreover, analyses on core samples might be influenced by deconfining and alteration of the core material, thus resulting in biased values. Therefore, hydraulic testing in a fresh borehole is the recommended method for determination of hydraulic conductivity in overconsolidated clays. However, the pressure perturbations induced by drilling activities have to be taken into account for design and analyses of hydraulic testing. The dissipation of drilling and installation of instrumentation 
induced pressure pertubations can be identified by the tidal components in the pore pressure time series. Our study showed that drilling the BDB-1 borehole with air as drilling fluid and a saturation with artificial porewater was an appropriate choice for our application, because: i) no mud-cake was created, ii) no artificial osmotic effects and borehole convergence were observed so far, iii) future water sampling can be carried out since there was no contamination with drilling mud, and iv) we reached fully undisturbed formation pressures after several months. The latter was possible to do so in an underground laboratory experiment, due no time and financial constraints, which are limiting factors on drill site for exploration boreholes. Therefore, in clay formations, particular care should be taken in the choice of drilling method and drilling fluid as well as borehole instrumentation materials, in order to obtain accurate hydraulic parameters.

\section{Acknowledgments}

482 This study was performed in the framework of the Deep Borehole experiment, financed by six 483 partners of the International Mont Terri Consortium (Swisstopo, NAGRA, BGR, GRS, 484 NWMO, IRSN).

485 The authors would like to thank Karam Kontar and Jocelyn Gisiger (Solexperts AG 486 Company) for their technical support and realisation of hydraulic testing, as well as Christelle 487 Courbet (IRSN) for advices on their interpretation. The MuStat package used in this paper is 488 the result of previous works respectively done by: Alain Mangin (CNRS, Laboratoire 489 d'écologie des hyrosystèmes de Moulis), David Labat (Géosciences Envionnement 490 Toulouse), Rachid Ababou (CNRS/INPT/IMFT), Hasan Fatmi (PhD at IRSN and 491 CNRS/INPT/IMFT) and David Bailly (TREES Institute). 


\section{References}

Ababou, R., Fatmi, H., Matray, J.-M., Nussbaum, C., Bailly, D., 2012. Statistical analyses of Pore Pressure Signals in Claystone During Excavation Works at the Mont Terri Underground Research Laboratory. In Rehab Abdel Rahman (Ed.), Radioactive Waste (pp. 373-430). InTech, ISBN: 978-953-51-0551-0

AF Consult, 2012. HA Experiment: Hydraulic Database Phases 1 - 16 Version 1.0. Mont Terri Technical Note 2010-74, 22 pp.

Altinier, M.V., 2006. Etude de la composition isotopique des eaux porales de l'argilite de Tournemire : inter-comparaison des méthodes de mesure et relations avec les paramètres pétrophysiques. Ph. D. dissertation, Université Paris-Sud 11, Orsay, France, $200 \mathrm{pp}$.

Archie, G.E., 1942. The electrical Resistivity Log as an Aid in Determining Some Reservoir Characteristics. Transactions of the American Institute of Mining Metallurgical, and Petroleum Engineers, 146, 54-62.

Bailly, D., Matray, J.-M., Ababou, R., 2014. Temporal behavior of a ventilated claystone at the Tournemire URL: Cross-spectral analyses focused on daily harmonics. Engineering Geology, 183, 137-158

Bailly, D., Matray, J.-M., 2015. LP-A Experiment: Phase 20, Statistical analysis of time series acquired in the EZ-B Niche and at the Main fault. Mont Terri TN 2014-59, 77p.

Barker, J.A., 1988. A Generalized Radial-Flow Model for Hydraulic Tests in Fractured Rock. Water Resources Research, 24(10), 1796-1804

Blaesi, H.R., Peters, T.J., Mazurek, M., 1991. Der Opalinus-Ton des Mt. Terri (Kanton Jura): Lithologie, Mineralogie und physiko-chemische Gesteinsparameter. Nagra Interner Bericht NAGRA NIB 9060. 
517 Boldt-Leppin, B.E.J., Hendry, J., 2003. Application of Harmonic Analysis of Water Levels to 518 Determine Vertical Hydraulic Conductivities in Clay-Rich Aquitards. Ground Water $519 \quad$ Vol. 41, No. 4, 514-522

520 Bossart, P. Thury, M. (2008). Mont Terri Rock Laboratory - Project, Programme 1996 to

Boulin, P.F., Bretonnier, P., Gland, N., Lombard, J.M., 2012. Contribution of the Steady State Method to Water Permeability Measurement in Very Low Permeability Porous Media. Oil and Gas Science and Technology, 67, 387-401.

Boving, T.B., Grathwohl, P., 2001. Tracer diffusion coefficients in sedimentary rocks: correlation between porosity and hydraulic conductivity. Journal of Contaminant Hydrogeology, 53, 1-2, 85-100.

Bredehoeft, J.D., 1967. Response of Well-aquifer Systems to Earth Tides. U.S., Geological Survey, Washington, D.C., 20242

Bredehoeft, J.D. and Papadopoulos, S.S. 1980. A method for determining the hydraulic properties of tight formations, Water Resources Research, 16(1): 233-238.

Butler, J.J., 1998. The Design and Performance, and Analysis of Slug Tests. Lewis Publishers (imprint of CRC Press LLC.) Boca Raton, Florida. 252 pp.

Chapuis, R. P. and Aubertin, M., 2003. Predicting the Coefficient of Permeability of Soils Using the Kozeny-Carman Equation. Département des génies civil, géologique et des mines, Ecole Polytechnique de Montréal, Montreal, 35 pp.

Croisé, J., Schilckenrieder, L., Marschall, P., Boisson, J.Y., Vogel, P., Yamamoto, S., 2004. Hydrogeological investigations in a low permeability claystone formation: the Mont Terri Rock Laboratory. Physics and Chemistry of the Earth, 29, 3-15. 
541 Cutillo, P.A., Bredehoeft, J.D., 2011. Estimating Aquifer Properties from the Water Level 542 Response to earth Tides. Ground Water, 49(4), 600-610

543 Doodson A.T., Warburg, H.D., 1941. Admiralty manual of tides. Her Majesty's Stationary $544 \quad$ Office, London, xii, $270 \mathrm{pp}$.

545 Fatmi, H., Ababou, R., Matray, J.-M., 2008. Statistical pre-processing analyses of 546 hydrometeorological time series in a geological clay site (methodology and first

Fatmi, H., 2009. Méthodologie d'analyse des signaux et caractérisation hydrogéologique : application aux chroniques de données obtenues aux laboratoires souterrains du Mont Terri, Tournemire et Meuse/Haute-Marne. PhD thesis, Université de Toulouse, $249 \mathrm{p}$.

Fernàndez-Garcia, D., Gómez-Hernández, J.J., Mayor, J.C., 2007. Estimating hydraulic conductivity of the Opalinus Clay at the regional scale: Combined effect of desaturation and EDZ. Clay in natural and engineered barriers for radioactive waste confinement - Part 2, 32, 8-14, 639-645.

Fierz, T., Rösli, U., 2014. Mont Terri DB Experiment: Installation of a 7-interval multi-packer system into borehole BDB-1 Instrumentation Report. Mont Terri Technical Note 2014-23, 37 pp.

Gautschi, A., 2001a. Hydrogeology of a fractured shale (Opalinus Clay): Implications for the deep disposal of radioactive wastes. Hydrogeology Journal, 9, 97-107.

Horseman, S.T., Higgo, J. J. W., Alexander, J., and Harrington, J. F., 1996. Water, Gas and Solute Movement Trough Argillaceous Media. Nuclear Energy Agency, 306 pp. 
564 Jaeggi, D., Hostettler, B., Residorf, N.N., 2017. Lithological facies and new stratigraphic correlations of the Opalinus Clay. Swiss Journal of Geosciences, (this volume).

566 Jiang, Z., Martiethoz, G., Taulis, M., Cox, M., 2013. Determination of vertical hydraulic conductivity of aquitards in a multi-layered leaky system using water-level signals in adjacent aquifers. Journal of Hydrology, 500, 170-182.

Johns, R.T., Vomvoris, S.G. and Löw, S., 1995. Review of hydraulic field tests in the Opalinus Clay of Northern Switzerland. In: Hydraulic and hydrochemical characterisation of argillaceous rocks. Proceedings of the International Workshop, Nottingham, UK, June 1994, Nuclear Energy Agency of the OECD, Paris, 167-177

Kell, G. S., 1975. Volume properties of ordinary water, in Handbook of Chemistry and Physics, 56th ed., edited by R. C. Weast, CRC Press, Cleveland, Ohio.

Keller, C.K., Van der Kamp, G., Cherry, J.A., 1989. A Multiscale Study of the Permeability of a Thick Clayey Till. Water Resources Research, Vol. 25, No. 11, 2299-2317.

Kostek, S., Schwartz, L., and Johnson, D., 1992. Fluid permeability in porous media: Comparison of electrical estimates with hydrodynamical calculations. Physical Review B 45(1), 186-194.

Marschall, P., Horseman, S., Gimmi, T., 2005. Characterisation of gas transport properties of the Opalinus Clay, a potential host rock formation for radioactive waste disposal. Oil and Gas Science and Technology, 60, No. 1, 121-139

Matray, J.M., Savoye, S., Cabrera, J., 2007. Desaturation and structure relationships around drifts excavated in the well-compacted Tournemire's argillite (Aveyron, France). Engineering Geology, 90, 1-16. 
Mazurek, M., Alt-Epping, P., Bath, A., Gimmi, T., Waber, H.N., 2009. Natural Tracer Profiles Across Argillaceous Formations: The CLAYTRAC Project. Nuclear Energy Agency (OECD/NEA) report, Paris, France, 365 pp.

Mejías, M., Renard, P., Glenz, D., 2009. Hydraulic testing of low-permeability formations: A case study in the granite of Cadalso de los Vidrios, Spain. Engineering Geology, $107,88-107$.

Melchior, P., 1978. The Tides of the Planet Earth. Pergamon Press, Oxford, 609 p.

Mercer, J. W., Pinder, G. F., and Donalson, I. G., 1975. A Galerkin-finite element analysis of the hydrothermal system at Wairakei, New-Zealand. Journal of Geophysical Research, 80, 2608-2621.

Merritt, M.L., 2004. Estimating hydraulic properties of the Floridan aquifer system by analysis of earth-tide, ocean-tide, and barometric effects. Collier and Hendry Counties, Florida. U.S. Geological Survey Water-resources investigations Report 03-4267, vi, $70 \mathrm{pp}$.

Monnier, G., Stengel, P., Fies, J.C., 1973. Une méthode de mesure de la densité apparente de petits agglomérats terreux. Application à l'analyse de système de porosité du sol. Annales Agronomiques, 24, 533-545.

Muñoz, J.J., Lloret, A., Alonso, E., 2003. Characterization of hydraulic properties under saturated and non saturated conditions: Project deliverable 4, Unpublished Technical Report, CIMNE.

Nagra (2002). Project Opalinus Clay: Safety Report, Demonstration of disposal feasibility for spent fuel, vitrified high-level waste and long-lived intermediate-level waste (Entsorgungsnachweis). Technical Report 02-05, 472 pp. 

2

Neuzil, C.E. 1982. On conducting the modified 'slug' test in tight formations. Water Resources Research, 18(2): 439-41.

Neuzil, C.E., 1994. How permeable are clays and shales? Water Resources Research, Vol. 30, No. 2, 145-150.

Neuzil, C.E., 2000. Osmotic generation of "anomalous" fuid pressures in geological environments. Nature, 403, 182-184.

Nussbaum, C., Bossart, P., 2004. Compilation of K-values from packer tests in the Mont Terri rock laboratory. Mont Terri Technical Note 2005-10, 29 pp.

Nussbaum, C., Bossart, P., Amann, F., Aubourg, C., 2011. Analysis of tectonic structures and excavation induced fractures in the Opalinus Clay, Mont Terri underground rock laboratory (Switzerland). Swiss Journal of Geosciences 104, 187-210.

Nussbaum, C., Kloppenburg, A., Caer, T. and Bossart, P., 2017. Tectonic evolution of the Mont Terri anticline based on forward modelling. Swiss Journal of Geosciences, (this volume).

Pape, H., Clauser, C., and Iffland, J., 1999. Permeability prediction based on fractal porespace geometry. Geophysics, 64, 1447-1460.

Pearson, F.J., Arcos, D., Boisson, J-Y., Fernández, A. M., Gäbler, H. E., Gaucher, E., Gautschi, A., Griffault, L., Hernán, P., Waber, N., 2003. Mont Terri Project Geochemistry of water in the Opalinus Clay Formation at the Mont Terri Rock Laboratory. Report of the FOWG, ํ5, Geology Series, $143 \mathrm{pp}$.

Peters, M., Mazurek, M., Jaeggi, D., Müller, H., 2011. WS-H Experiment: Heterogeneities in the sandy facies of Opalinus Clay on a scale on millimetres to centimeters. Mont Terri Technical Note 2010-76, 66 pp. 
632 Terzaghi, V.K., 1936. The Sheering Resistance of Saturated Soils and the Angle between the Planes of Shear. First International Conference of Soil Mechanics, Harvard University, Vol. 1, 54-46.

Timms, W.A., and Acworth, R.I., 2005. Propagation of pressure change through thick clay sequences: An example from Liverpool Plains, NSW, Australia. Hydrogeology Journal, 13, No. 5-6, 858-870.

638 Tremosa, J., 2010. Influence of osmotic processes on the excess-hydraulic head measured in 639 the Toarcian/Domerian argillaceous formation of Tournemire. Ph. D. dissertation, Université Pierre et Marie Curie, Paris VI, France, 322 pp.

Ullman, W.J., and Aller, R.C., 1982. Diffusion Coefficients in Nearshore Marine Sediments. Limnology and Oceanography, 27, 552-556.

Unesco, 1981. Tenth report on the joint panel on oceanographic tables and standard. Sidney, BC, Canada. 1-5 september 1980. Unesco technical paper in marine science, 36, 28 pp.

Van der Kamp, G., 2001. Methods for determining the in situ hydraulic conductivity of shallow aquitards: an overview. Hydrogeology Journal, 9, 5-16.

Van Loon, L.R., Soler, J.M., Jakob, A., Bradbury, M.H., 2003b. Effect of confining pressure on the diffusion of $\mathrm{HTO},{ }^{36} \mathrm{Cl}^{-}$and ${ }^{125} \mathrm{I}^{-}$in a layered argillaceous rock (Opalinus Clay): diffusion perpendicular to the fabric. Applied Geochemistry, 18, 1653-1662.

Van Loon, L.R., Mibus, J., 2015. A modified version of Archie's law to estimate effective diffusion coefficients of radionuclides in argillaceous rocks and its application in safety analysis studies. Applied Geochemistry, 59, 85-94. 
654 Wiegel, R.L., 1964. Tsunamis, storm surges, and harbour oscillations. Ch. 5 in 655 Oceanographical Engineering, Prentice Hall, Englewood Cliffs, New Jersey, 95$4656 \quad 127$

6

7

8657 Yu, L., Rogiers B., Gedeon, M., Marivoet J., Craen, M.D., Mallants, D., 2013. A critical 658 review of laboratory and in-situ hydraulic conductivity measurements for the Boom 659 Clay in Belgium, Applied Clay Science, 75-76, 1-12 


\section{Figure captions}

2 Fig. 1: Geological cross-section of the Mont Terri anticline (adapted from Nussbaum et al, 32017 , this volume). Location of the rock laboratory is indicated by a white line. The BDB-1

4 deep borehole, represented by a thick black line, crosses the lower part of the Dogger aquifer,

5 the entire Opalinus Clay formation and the upper part of the Liassic marls.

6 Fig. 2: a) Stratigraphic sequence along the BDB-1 borehole; b) BDB-1 borehole layout; c)

7 Double packer elements.

8 Fig. 3: Experimental set up for: a) pulse withdrawal tests; b) constant rate pumping tests 9 performed on BDB-1 borehole ( ${ }^{\text {SSOlexperts}) . ~}$

10 Fig. 4: Records of pore pressure responses in the seven intervals of BDB-1 borehole to: a) 11 pulse tests; b) constant rate withdrawal tests

12 Fig. 5: Petrophysical parameters acquired along BDB-1 borehole: a) Water accessible 13 porosity acquired by oven-drying at $105^{\circ} \mathrm{C}$; b) Specific surface area obtained by BJH and 14 BET methods; c) Grain density estimated by helium pycnometry on oven dried samples.

15 Fig. 6: a) Intrinsic permeability profile and b) hydraulic conductivity profile computed across 16 the Opalinus Clay and the Passwang formation for cementation factor of 2, 2.3 and 2.5.

17 Fig. 7: System compressibility computed from pulse testing in BDB-1 borehole. Dashed line 18 represents the water compressibility at $10^{\circ} \mathrm{C}$. The outlier in the lower part of the borehole is 19 due to a very low withdrawn volume.

20 Fig. 8: Comparison of the different tests performed on BDB-1 borehole: a) degree of 21 dissipation associated to the recovery phases of pulse withdrawal tests; b) normalised 22 pressure drawdown during constant rate withdrawal tests and c) degree of dissipation 23 following the end of the withdrawal phase. 
24 Fig. 9: Example of residual plots for the optimization of Interval 2 (OPA shaly facies) pulse 25 sequence fit to the Cartesian pressure response using a) an homogeneous model and b) a 26 composite model with skin.

27 Fig. 10: a) Simulation of a pulse test performed on BDB-1 Interval 5 located in the upper 28 shaly facies of Opalinus Clay and b) associated Ramey A plot with best fit parameters. 29 Results of 200 perturbation analyses and their confidence regions (c and d).

30 Fig. 11: Estimated RMS spectrum of pore pressure time series measured in BDB-1 borehole 31 between 01/09/2014 and 10/03/2015. The following tides are observable: principal lunar 32 semidiurnal tide $\mathrm{M}_{2}\left(2.236 \cdot 10^{-5} \mathrm{~Hz}\right)$ and solar semidiurnal tide $\mathrm{S}_{2}\left(2.315 \cdot 10^{-5} \mathrm{~Hz}\right)$, lunar 33 diurnal tides $\mathrm{K}_{1}\left(1.161 \cdot 10^{-5} \mathrm{~Hz}\right)$ and $\mathrm{O}_{1}\left(1.076 \cdot 10^{-5} \mathrm{~Hz}\right)$, and the solar diurnal components $\mathrm{S}_{1}$ $34\left(1.157 \cdot 10^{-5} \mathrm{~Hz}\right)$ and $\mathrm{P}_{1}\left(1.154 \cdot 10^{-5} \mathrm{~Hz}\right)$

35 Fig. 12: Comparison of results obtained by petrophysical analysis, in situ hydraulic testing 36 and tidal spectral analysis performed on BDB-1 borehole: a) hydraulic conductivity; b) 37 specific storage

38 Fig. 13: Compilation of results from field permeability tests performed on the Opalinus Clay 39 at the Mont Terri underground laboratory outside the excavated damaged zone (modified 40 from AF Consult, 2012). 
1 Table captions

2 Table 1: Specifications of the pressure and temperature sensors installed in BDB-1 borehole.

3 Table 2: Plausibility ranges set in nSIGHTS for fitted parameters. K stands for hydraulic

4 conductivity and Ss for specific storage. Skin zone conductivity ranges were set one order of 5 magnitude higher compared to intact rock.

6 Table 3: Parameter estimates from BDB-1 borehole pulse withdrawal tests and constant rate 7 (CR) withdrawal tests $\left(\mathrm{K}\left[\mathrm{m} \mathrm{s}^{-1}\right]\right.$ : hydraulic conductivity; $\mathrm{Ss}\left[\mathrm{m}^{-1}\right]$ : specific storage; $\mathrm{n}$ : flow 8 dimension; $t_{\mathrm{s}}[\mathrm{cm}]$ : skin thickness). Shaded cells represent unrealistically wide range of 9 uncertainties.

10 Table 4: Amplitudes of the tidal components with associated frequencies observed on BDB-1 11 pore pressure time series between $01 / 09 / 2014$ and 10/03/2015

12 Table 5: Specific storage coefficients $\left(\mathrm{S}_{\mathrm{s}}\right)$ estimated from absolute pore pressure signals for 13 BDB-1 borehole measuring intervals with corresponding formations and amplitudes of 14 pressure head fluctuations $\Delta \mathrm{h}$.

15 Table 6: Spectral coherence function (Coh), arithmetic mean of the specific storativity 16 coefficient $\left(\tilde{\mathrm{S}_{\mathrm{s}}}\right)$, amplitude of the pore pressure signal $1\left(\mathrm{~A}_{\mathrm{z} 1}\right)$, and of the pore pressure signal $172\left(\mathrm{~A}_{\mathrm{z} 2}\right)$, vertical effective amplitude hydraulic conductivity $\left(\tilde{\mathrm{K}_{v}}{ }^{\mathrm{Amp}}\right)$ and vertical effective 18 phase hydraulic conductivity $\left(\tilde{\mathrm{K}_{v}}{ }^{\Delta} \varphi\right)$, effective dynamic porosity $(\omega)$ obtained for the $\mathrm{M}_{2}$ earth 19 tide for different couples of sensors in BDB-1 borehole. Mean water-loss porosity ( $\left.\omega_{\text {water loss }}\right)$ 20 is given for comparison purposes. Shaded cells indicate spurious values. 


\section{Alsace Molasse}

Reuchette Formation

Courpenay Formation

Vellerat Formation

St-Ursanne Formation

Baerschwl Formation

Henthal Formation

Hauptrogenstein Formation

Passwang Formation

Opalinus Clay Formation

Stallelegg Formation

Klettgau Formation

Bankerjoch Formation

Schinznach Formation

Zeglingen Formation

Kaiseraugst Formation

Permo-Carboniferous sediments ?

i:: Basement undifferentiated
NNW

SSE

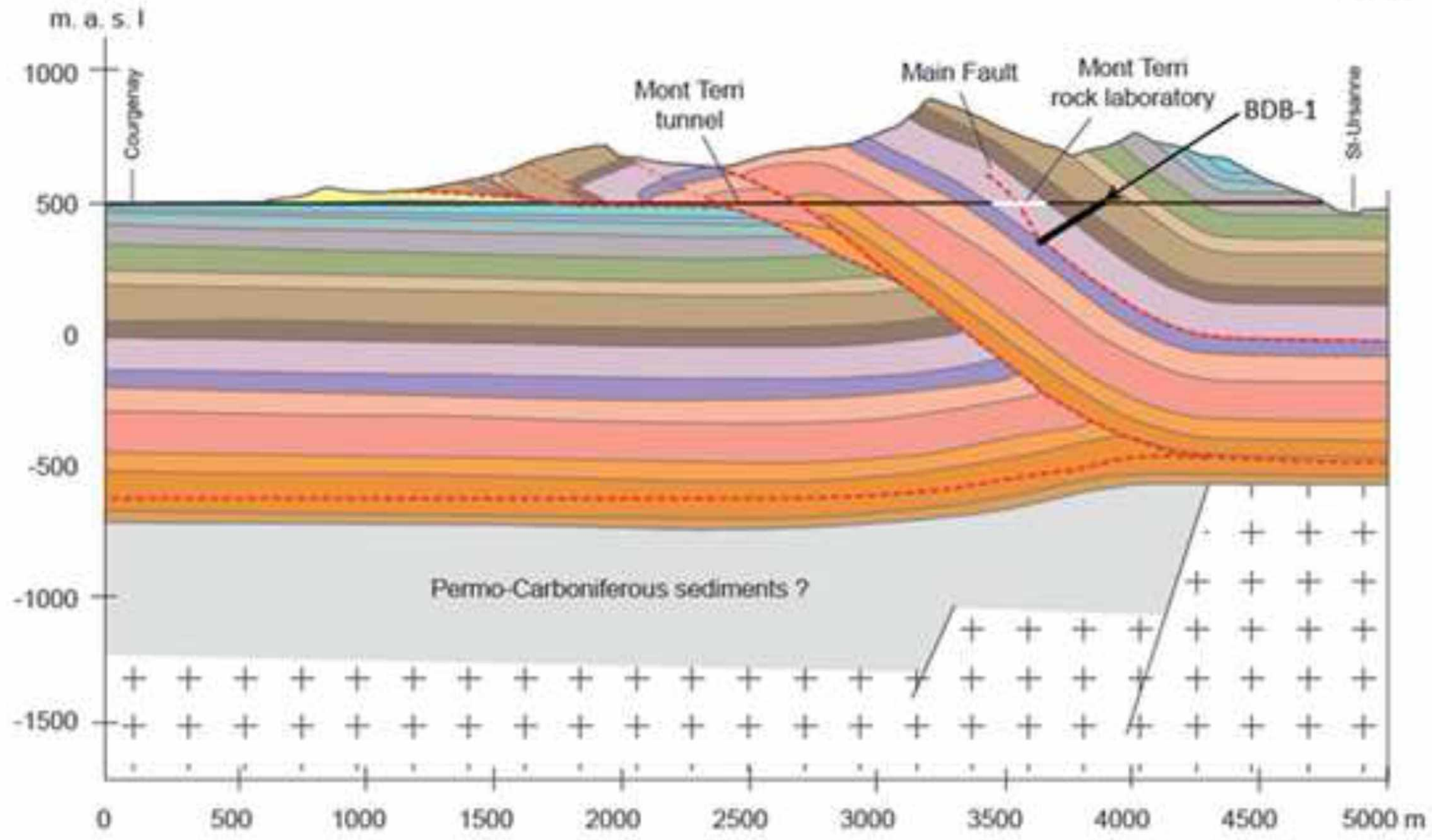

/ Extensionat faults 
a)

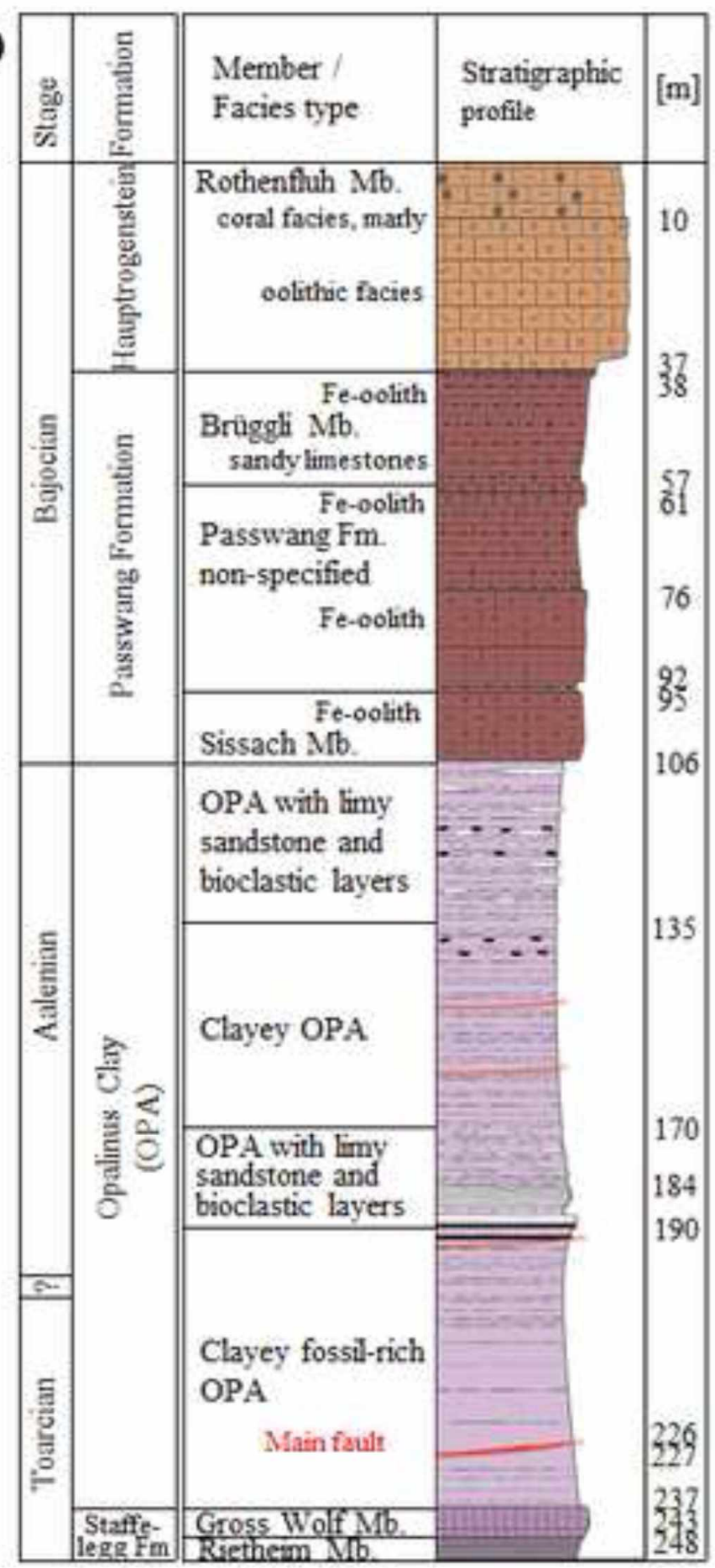

b) C) Cemented
annulus 
a)

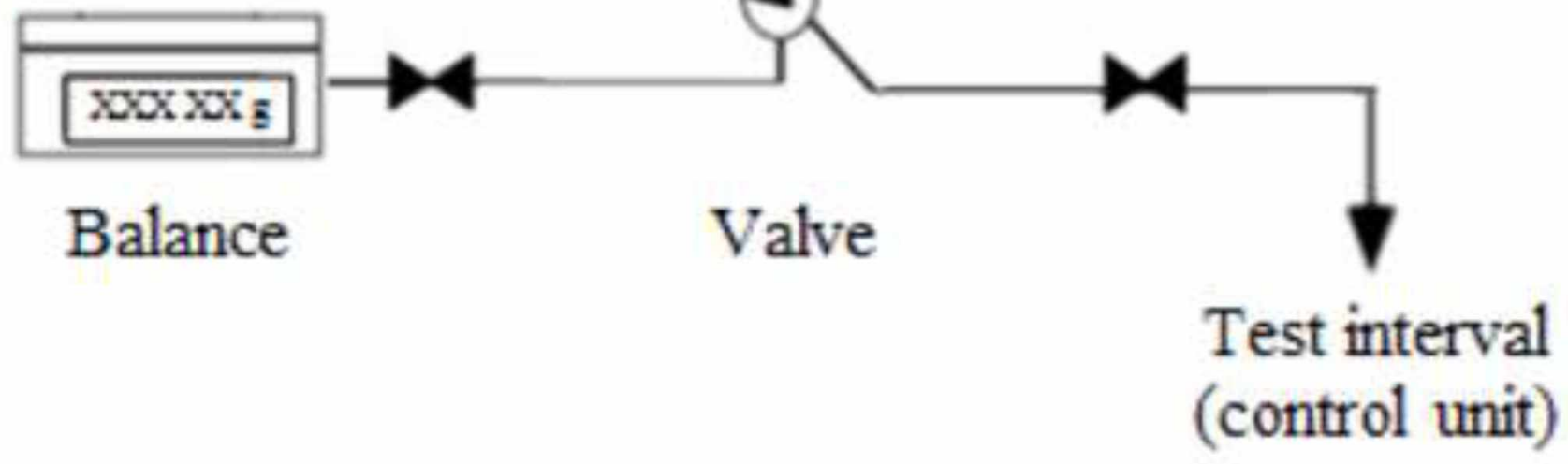

b)

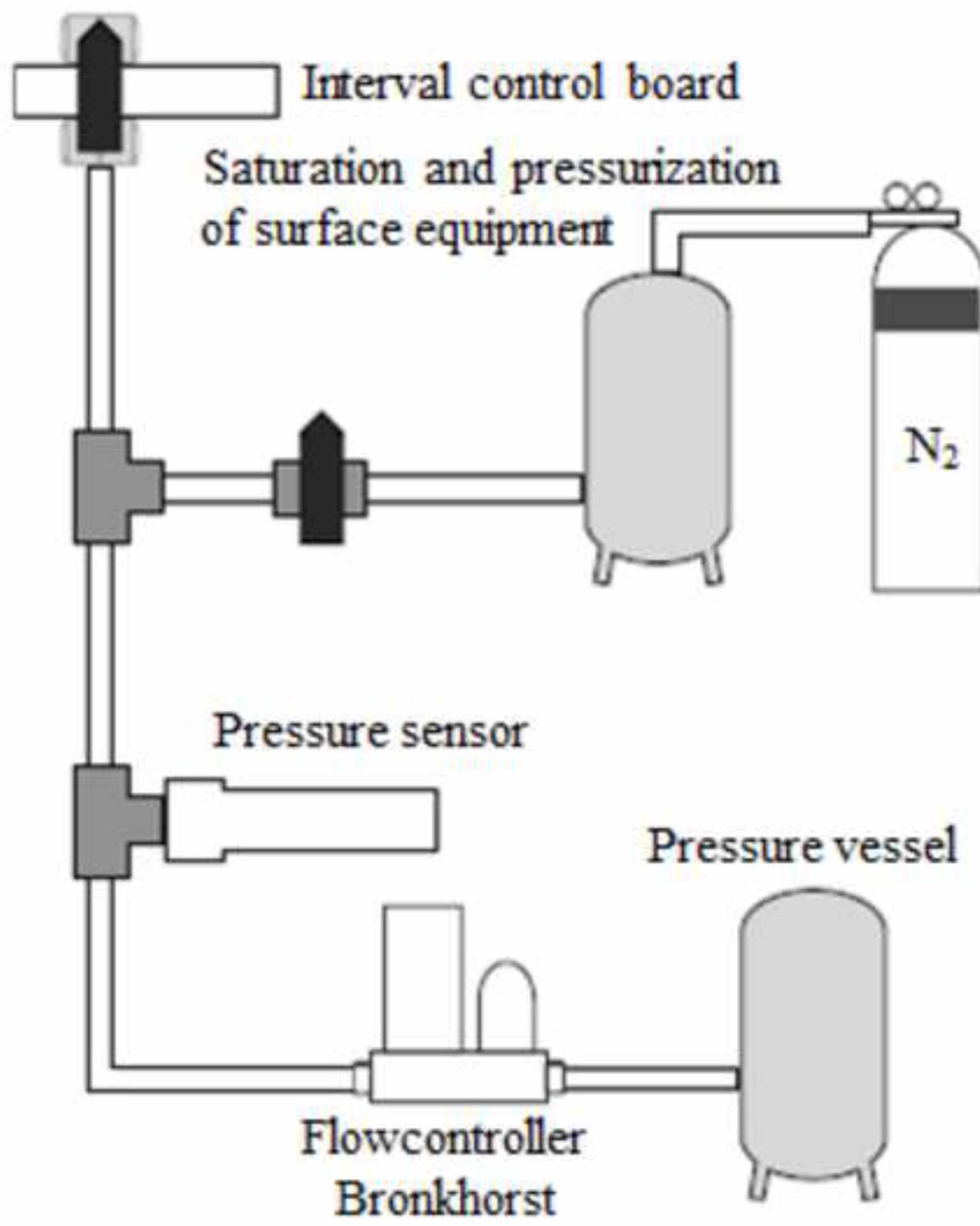



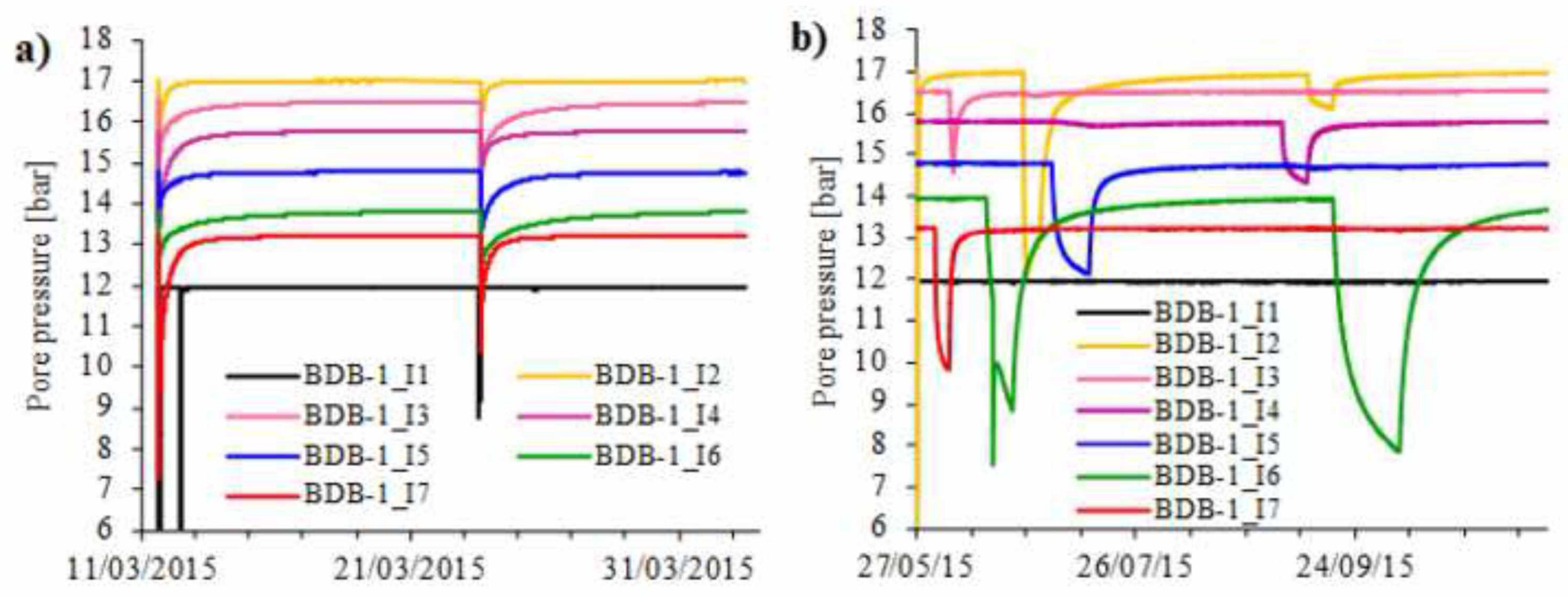
a) Water-accessible porosity [vol\%]

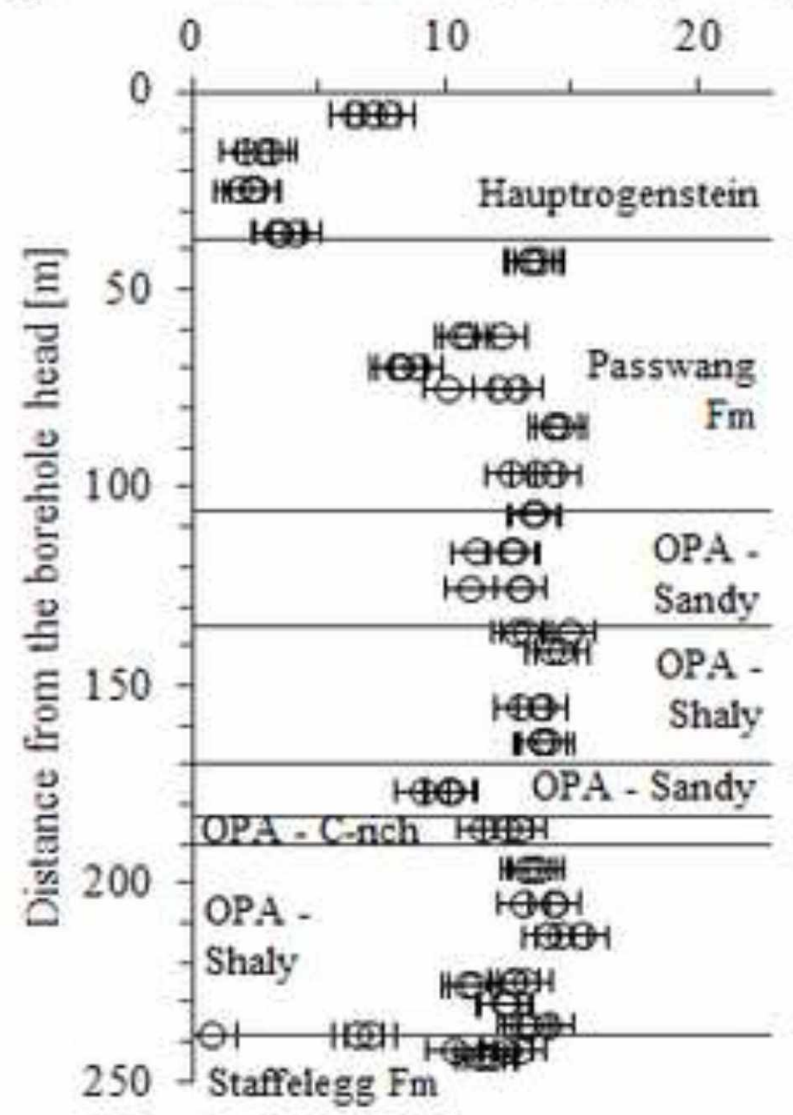

b) Specific surface area $\left[\mathrm{m}^{2}, \mathrm{~g}^{-1}\right]$

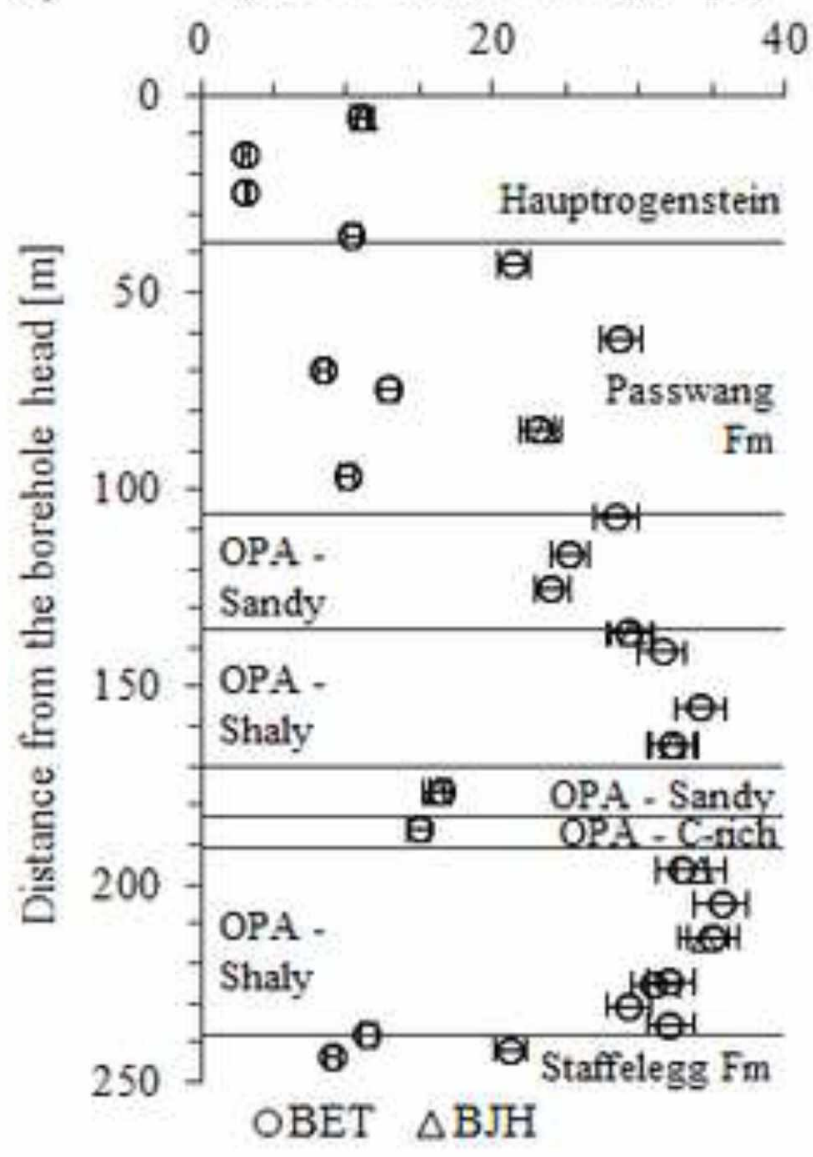

c) Grain density $\left[\mathrm{g} \cdot \mathrm{cm}^{-3}\right]$

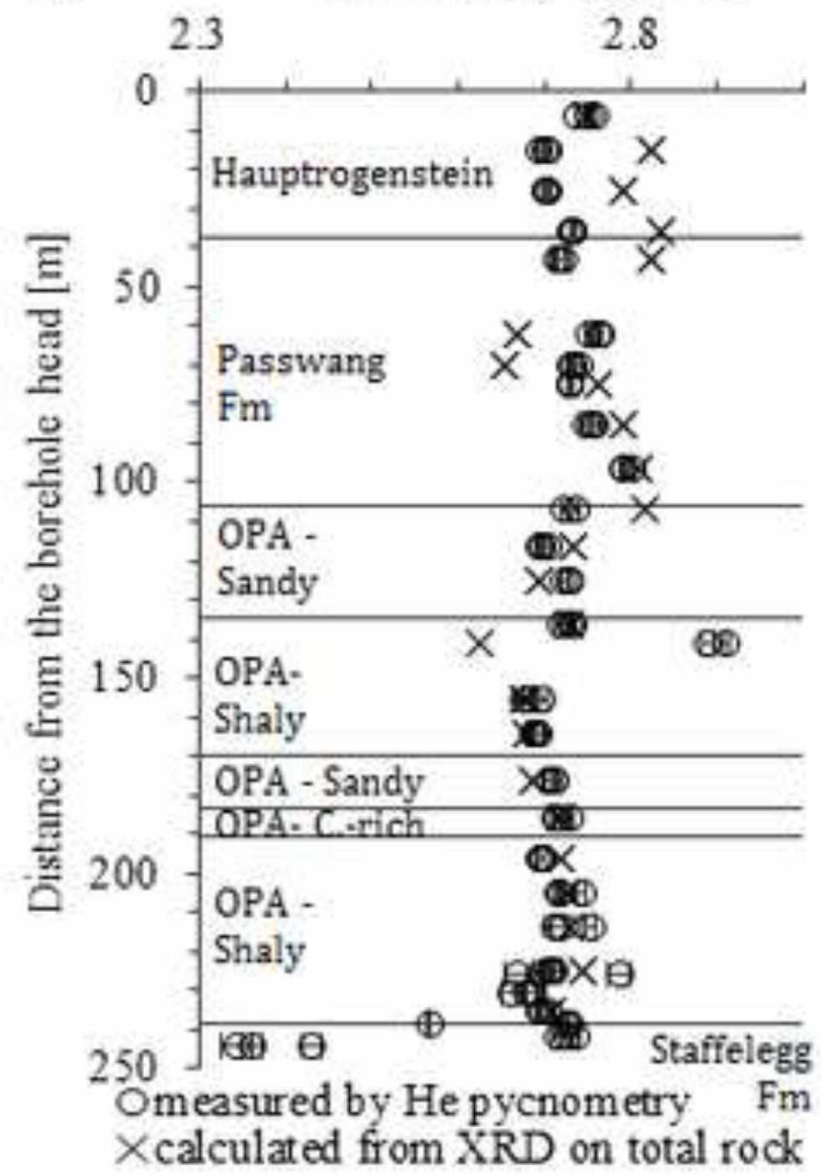


Distance from the borehole head $[\mathrm{m}]$

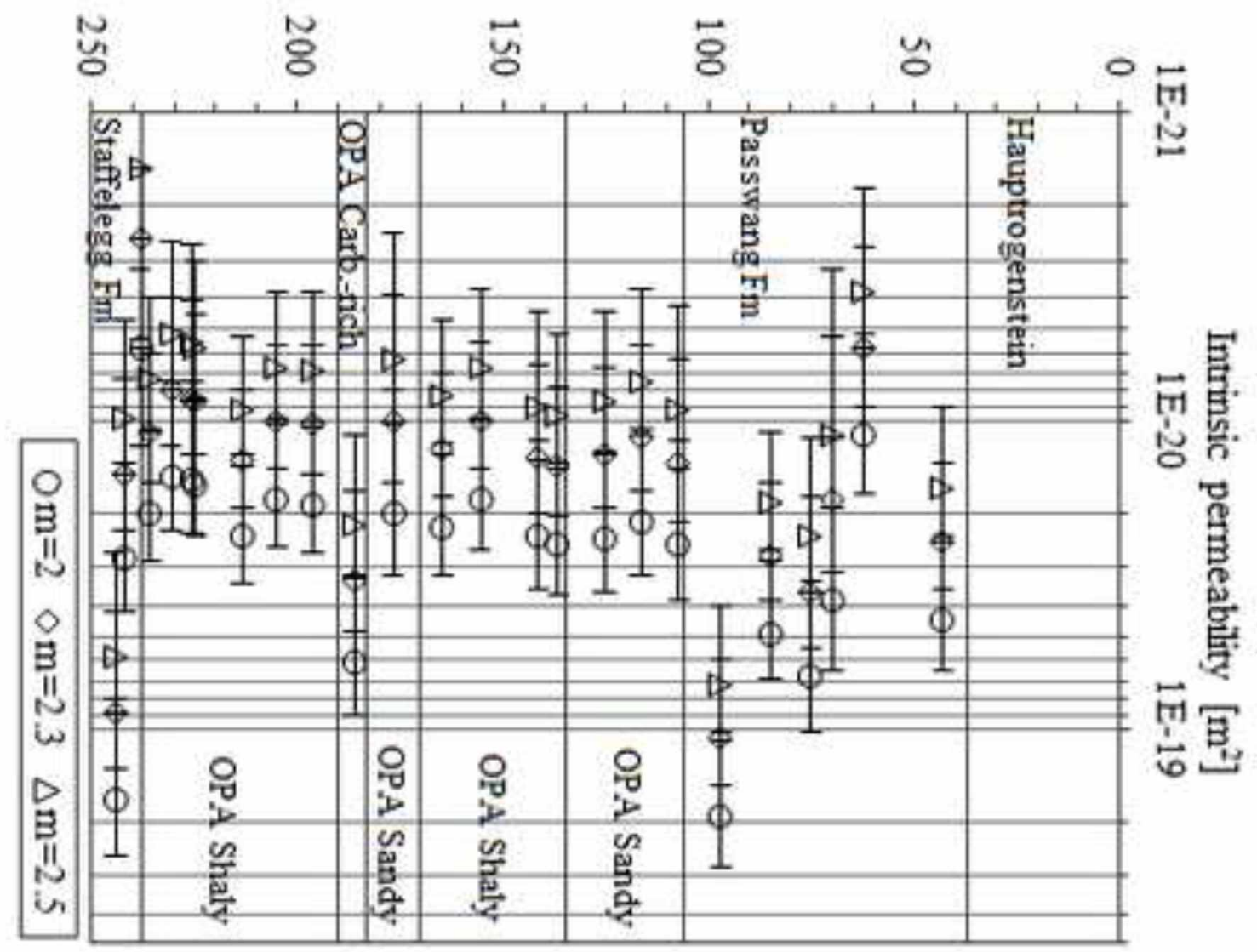

Distance from the borehole head [m]

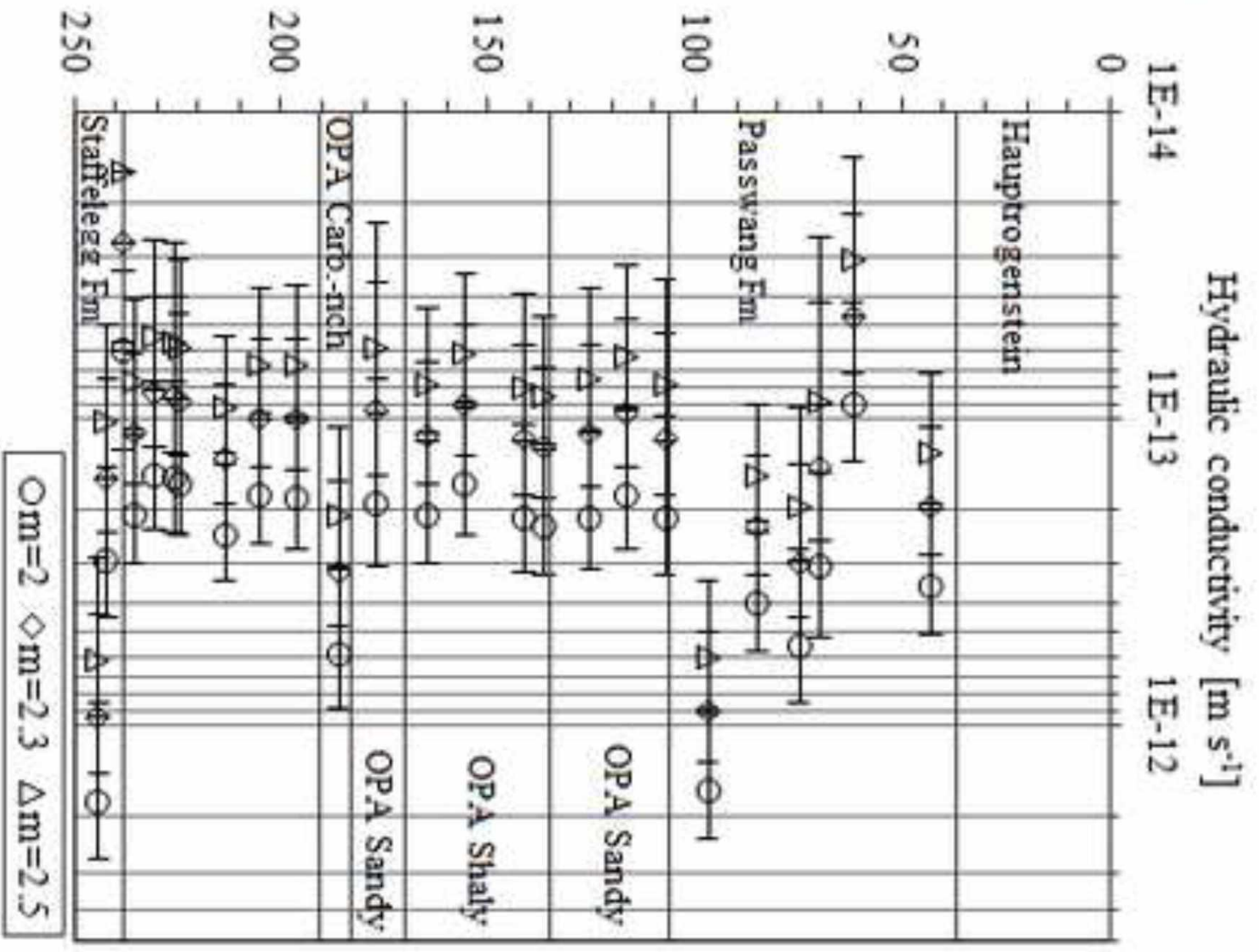




\section{Compressibility $\left[\mathrm{Pa}^{-1}\right]$}

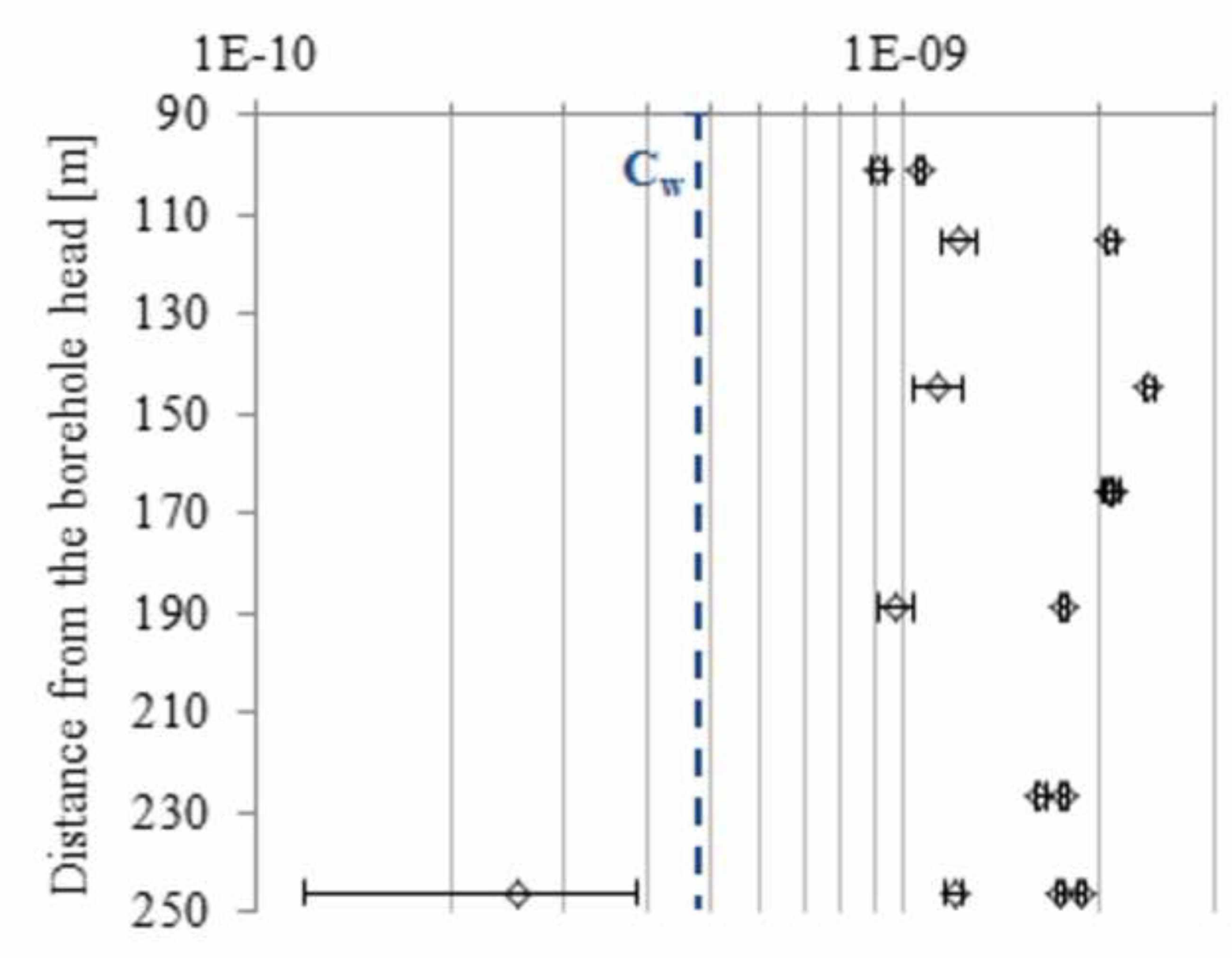



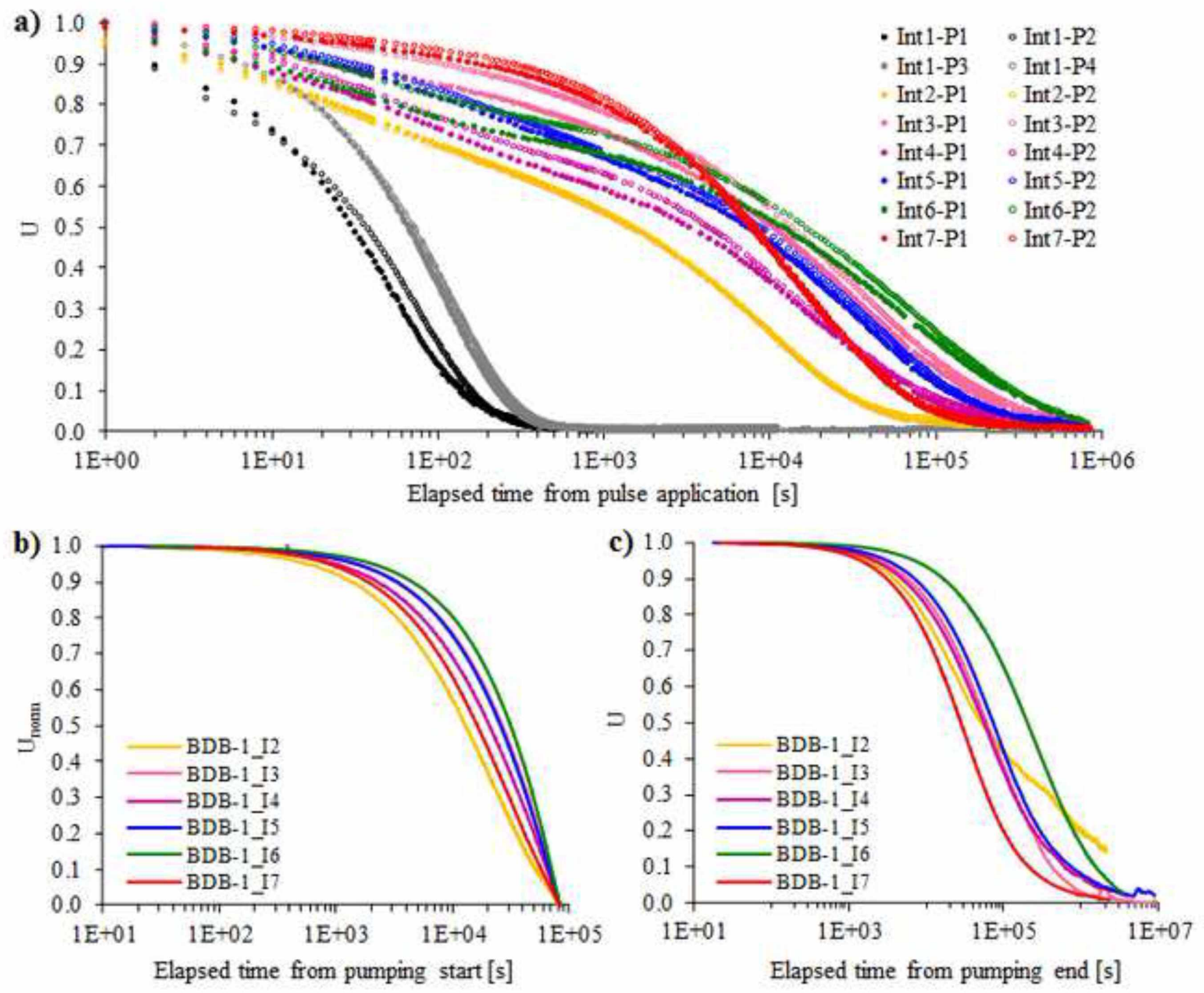

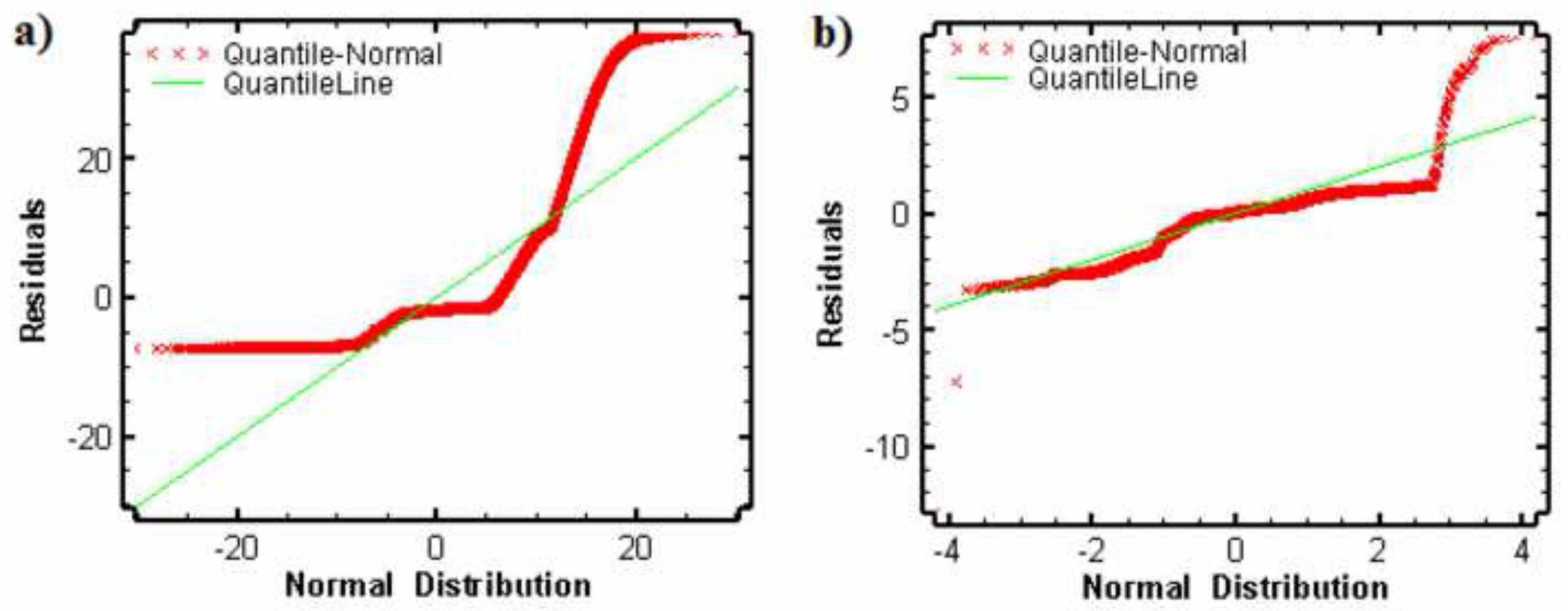
a)

c)
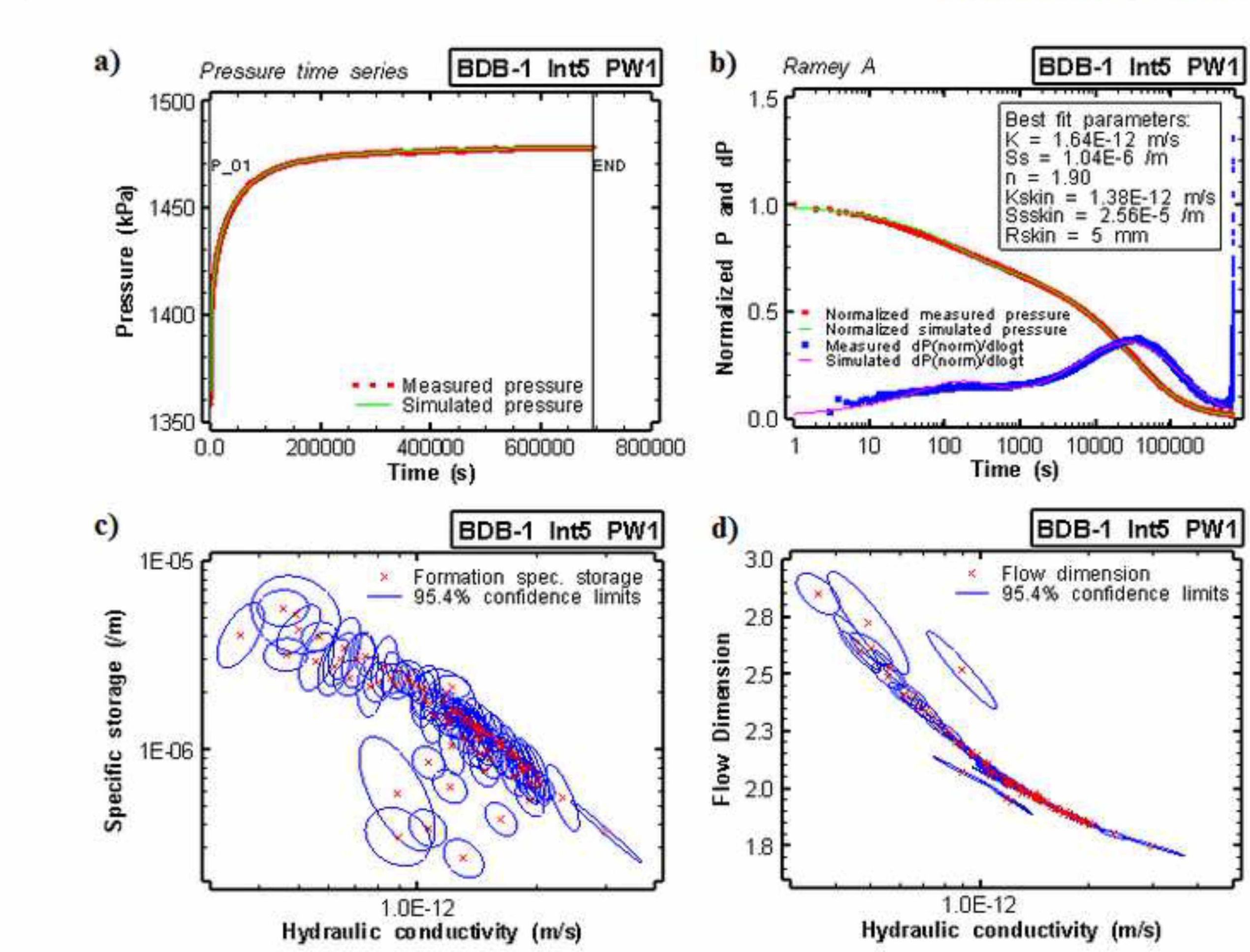

d)

Hydraulic conductivity $(\mathrm{m} / \mathrm{s})$
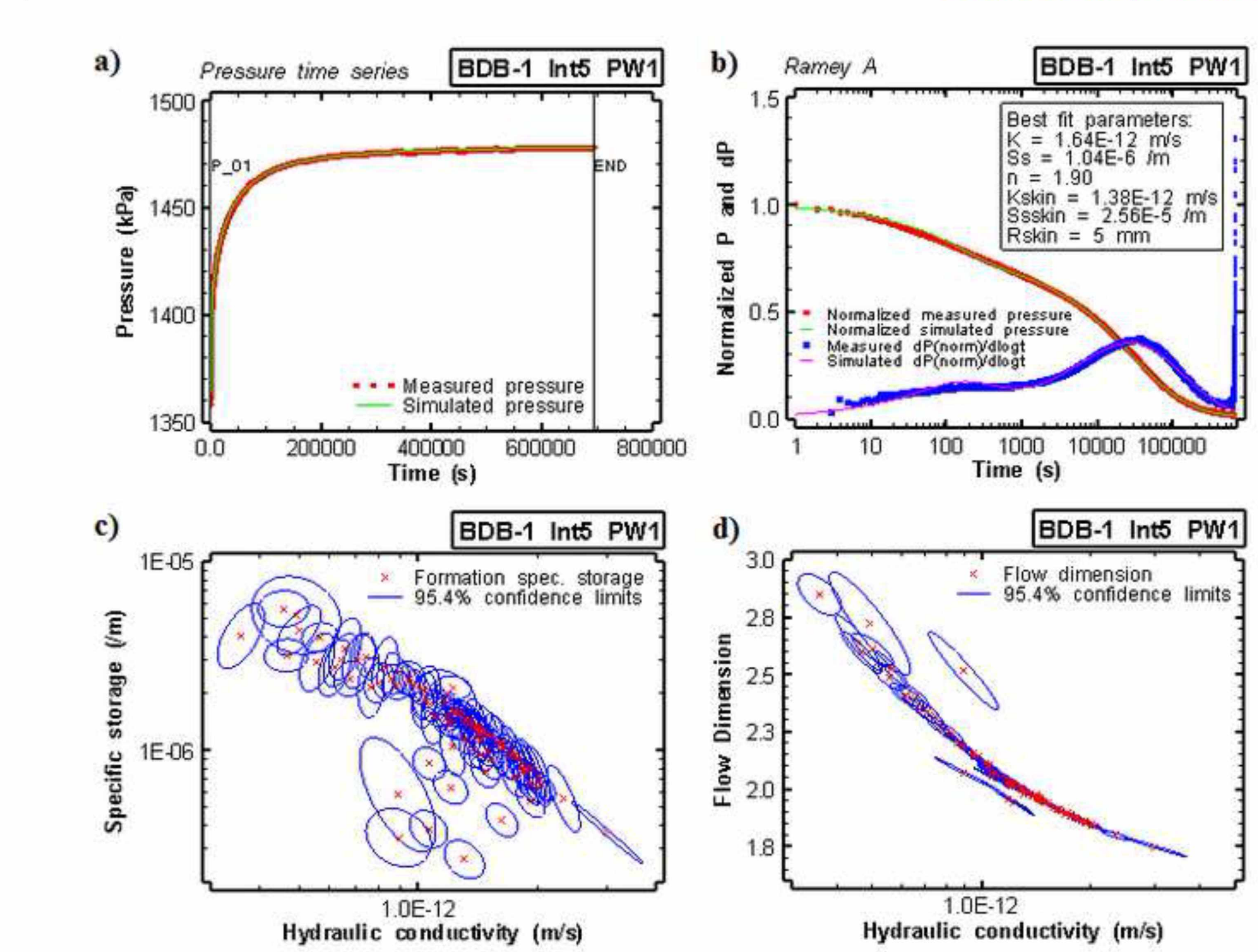

\section{Figure 10}

Click here to download Figure Yu_et_al_Fig10.png $\underline{\underline{\underline{*}}}$ 
a)

Hydraulic conductivity [ $\mathrm{m} \mathrm{s}^{-1}$ ]

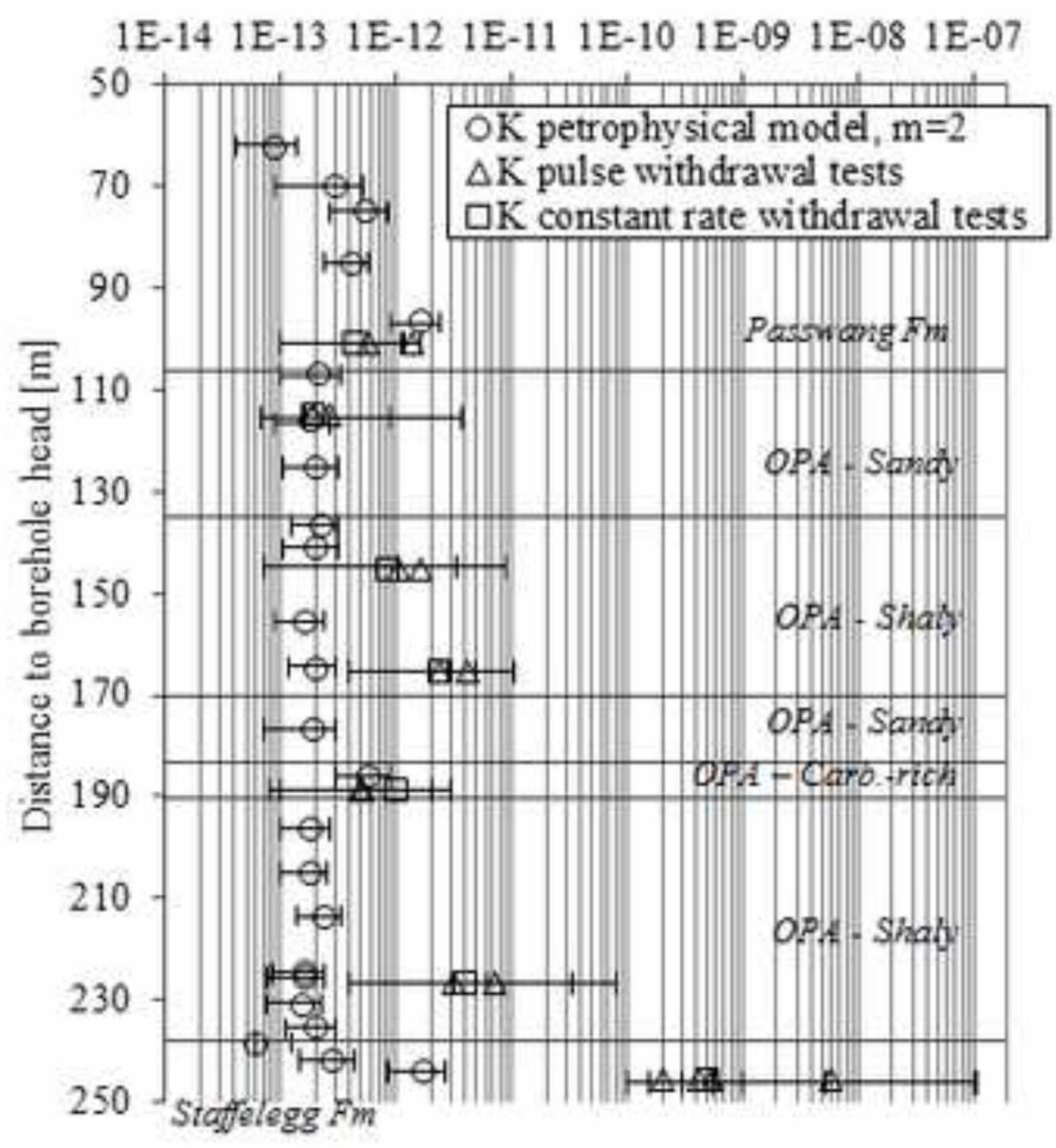

b)

Specific storage $\left[\mathrm{m}^{-1}\right]$

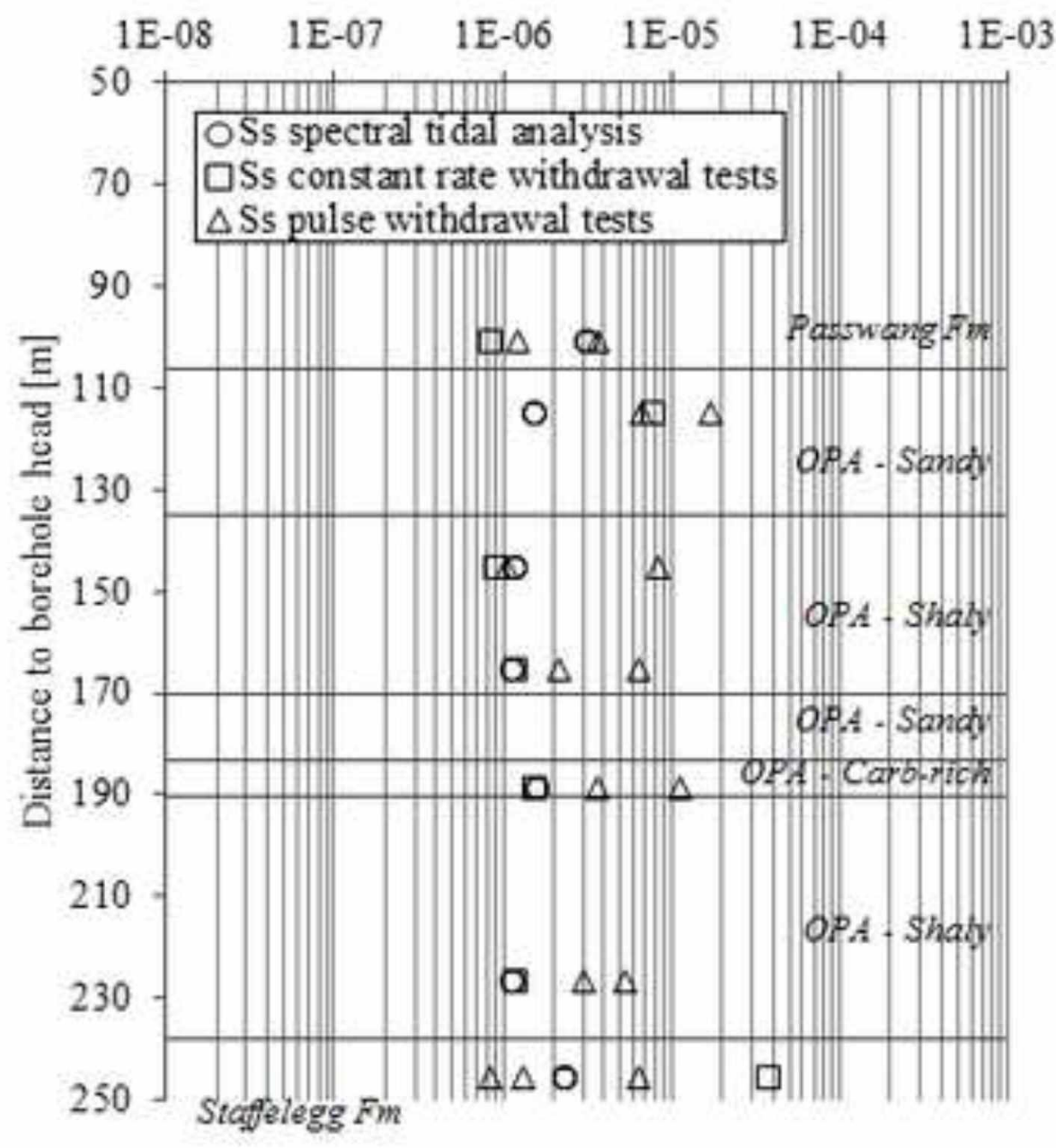




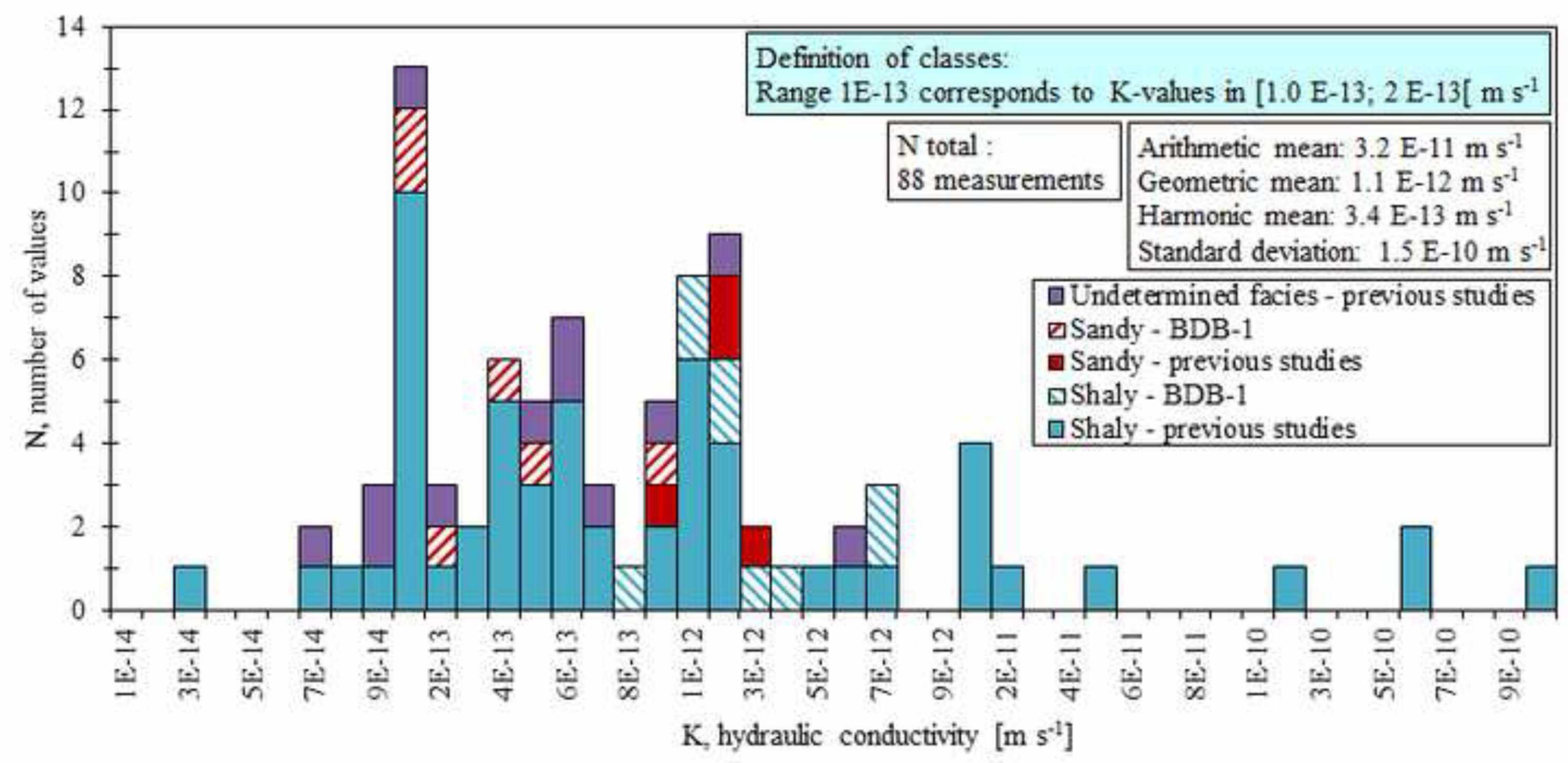




\begin{tabular}{lcc}
\hline Sensor type & Temperature & Pore pressure \\
\hline Model & IST AG PT1000 & Keller AG PAA-33X \\
Validity range & $-50-650{ }^{\circ} \mathrm{C}$ & $0-50$ bars (absolute) \\
Accuracy & $\pm(0.15+0.002|\mathrm{~T}|)^{\circ} \mathrm{C}$ & $0.05 \% \mathrm{FS}$ \\
\hline
\end{tabular}

1 


$\begin{array}{lll}\mathrm{K}\left[\mathrm{m} \mathrm{s}^{-1}\right] & \text { Interval } 1 & 10^{-13}-10^{-8} \\ & \text { Interval } 2 \text { to } 7 & 10^{-13}-10^{-11}\end{array}$

Ss $\left[\mathrm{m}^{-1}\right]$

$10^{-8}-10^{-4}$

Flow dimension [-]

$1-3.5$

Skin thickness [cm]

$0.5-30$

External boundary radius [m] $0-5$ 


\begin{tabular}{|c|c|c|c|c|c|c|c|c|c|c|}
\hline \multirow[t]{3}{*}{ Test } & \multirow[t]{3}{*}{ Interval } & \multirow[t]{3}{*}{$\mathrm{t}_{\mathrm{s}}[\mathrm{cm}]$} & \multirow{2}{*}{\multicolumn{2}{|c|}{$\frac{\mathrm{K}\left[\mathrm{m} \cdot \mathrm{s}^{-1}\right]}{\text { Formation }}$}} & \multicolumn{3}{|c|}{$\mathrm{S}_{\mathrm{s}}\left[\mathrm{m}^{-1}\right]$} & \multicolumn{3}{|c|}{$\mathrm{n}$} \\
\hline & & & & & Skin & Formation & & Skin & & \\
\hline & & & Range & Best fit & Best fit & Range & Best fit & Best fit & Range & Best fit \\
\hline \multicolumn{11}{|l|}{ Pulse } \\
\hline C1-1 & $\mathrm{I}_{1}$ & - & $1 \cdot 10^{-10}-3.5 \cdot 10^{-10}$ & $2.1 \cdot 10^{-10}$ & - & $6 \cdot 10^{-9}-6.3 \cdot 10^{-8}$ & $1.4 \cdot 10^{-8}$ & - & $1.9-2.7$ & 2.2 \\
\hline C1-2 & $\mathrm{I}_{1}$ & - & $1 \cdot 10^{-11}-1 \cdot 10^{-7}$ & $4.2 \cdot 10^{-10}$ & - & & $1.4 \cdot 10^{-6}$ & - & & 2.0 \\
\hline C1-3 & $\mathrm{I}_{1}$ & - & $1 \cdot 10^{-11}-1 \cdot 10^{-7}$ & $5.6 \cdot 10^{-10}$ & - & & $6.3 \cdot 10^{-8}$ & - & & 2.4 \\
\hline C1-6 & $\mathrm{I}_{1}$ & - & $3 \cdot 10^{-11}-1 \cdot 10^{-8}$ & $5.9 \cdot 10^{-9}$ & - & & $8.3 \cdot 10^{-7}$ & - & & 2.0 \\
\hline $\mathrm{C} 2-1$ & $\mathrm{I}_{2}$ & 0.5 & $2 \cdot 10^{-12}-3 \cdot 10^{-11}$ & $3.1 \cdot 10^{-12}$ & $7.8 \cdot 10^{-12}$ & $1 \cdot 10^{-7}-3 \cdot 10^{-5}$ & $5.2 \cdot 10^{-6}$ & $4.3 \cdot 10^{-5}$ & $1.8-3.0$ & 2.8 \\
\hline $\mathrm{C} 2-2$ & $\mathrm{I}_{2}$ & 0.5 & $2 \cdot 10^{-12}-1 \cdot 10^{-10}$ & $7.3 \cdot 10^{-12}$ & $1.0 \cdot 10^{-11}$ & $1 \cdot 10^{-7}-2 \cdot 10^{-5}$ & $3.0 \cdot 10^{-6}$ & $4.7 \cdot 10^{-5}$ & $1.4-2.9$ & 2.0 \\
\hline C3-1 & $\mathrm{I}_{3}$ & 0.5 & $1 \cdot 10^{-13}-3 \cdot 10^{-12}$ & $5.1 \cdot 10^{-13}$ & $1.6 \cdot 10^{-12}$ & $5 \cdot 10^{-7}-3 \cdot 10^{-5}$ & $3.7 \cdot 10^{-6}$ & $1.2 \cdot 10^{-5}$ & $1.4-3.1$ & 2.1 \\
\hline $\mathrm{C} 3-2$ & $\mathrm{I}_{3}$ & 0.5 & $2 \cdot 10^{-13}-2 \cdot 10^{-12}$ & $4.9 \cdot 10^{-13}$ & $1.6 \cdot 10^{-12}$ & $2 \cdot 10^{-6}-3 \cdot 10^{-5}$ & $1.1 \cdot 10^{-5}$ & $1.5 \cdot 10^{-5}$ & $1.4-3.4$ & 2.5 \\
\hline $\mathrm{C} 4-1$ & $\mathrm{I}_{4}$ & 0.5 & $1 \cdot 10^{-12}-9 \cdot 10^{-12}$ & $2.3 \cdot 10^{-12}$ & $5.7 \cdot 10^{-12}$ & $2 \cdot 10^{-6}-1 \cdot 10^{-5}$ & $6.4 \cdot 10^{-6}$ & $5.5 \cdot 10^{-5}$ & $1.7-3$ & 2.3 \\
\hline $\mathrm{C} 4-2$ & $\mathrm{I}_{4}$ & 2.0 & $7 \cdot 10^{-13}-1 \cdot 10^{-11}$ & $4.2 \cdot 10^{-12}$ & $2.7 \cdot 10^{-11}$ & $1 \cdot 10^{-6}-2 \cdot 10^{-5}$ & $2.2 \cdot 10^{-6}$ & $9.7 \cdot 10^{-6}$ & $1.5-3$ & 2.0 \\
\hline C5-1 & $\mathrm{I}_{5}$ & 0.5 & $4 \cdot 10^{-13}-4 \cdot 10^{-12}$ & $1.6 \cdot 10^{-12}$ & $1.4 \cdot 10^{-12}$ & $3 \cdot 10^{-7}-8 \cdot 10^{-6}$ & $1.0 \cdot 10^{-6}$ & $2.6 \cdot 10^{-5}$ & $1.8-2.9$ & 1.9 \\
\hline $\mathrm{C} 5-2$ & $\mathrm{I}_{5}$ & 0.5 & $4 \cdot 10^{-13}-3 \cdot 10^{-12}$ & $1.0 \cdot 10^{-12}$ & $2.7 \cdot 10^{-12}$ & $1 \cdot 10^{-6}-3 \cdot 10^{-5}$ & $8.5 \cdot 10^{-6}$ & $4.7 \cdot 10^{-5}$ & $1-3$ & 2.5 \\
\hline C6-1 & $\mathrm{I}_{6}$ & 1.5 & $8 \cdot 10^{-14}-8 \cdot 10^{-13}$ & $1.9 \cdot 10^{-13}$ & $1.4 \cdot 10^{-11}$ & $8 \cdot 10^{-7}-1 \cdot 10^{-5}$ & $6.6 \cdot 10^{-6}$ & $6.6 \cdot 10^{-6}$ & $1.7-3$ & 2.6 \\
\hline C6-2 & $\mathrm{I}_{6}$ & 0.5 & $2 \cdot 10^{-13}-6 \cdot 10^{-13}$ & $2.7 \cdot 10^{-13}$ & $5.4 \cdot 10^{-12}$ & $1 \cdot 10^{-6}-2 \cdot 10^{-5}$ & $1.7 \cdot 10^{-5}$ & $2.9 \cdot 10^{-5}$ & $1.7-3$ & 2.8 \\
\hline C7-1 & $\mathrm{I}_{7}$ & 0.5 & $3 \cdot 10^{-13}-4.5 \cdot 10^{-12}$ & $5.8 \cdot 10^{-13}$ & $3.7 \cdot 10^{-13}$ & $4 \cdot 10^{-7}-2 \cdot 10^{-5}$ & $3.7 \cdot 10^{-6}$ & $1.9 \cdot 10^{-6}$ & $1.9-3.5$ & 3.0 \\
\hline $\mathrm{C} 7-2$ & $\mathrm{I}_{7}$ & 0.5 & $4 \cdot 10^{-13}-2.0 \cdot 10^{-12}$ & $1.4 \cdot 10^{-12}$ & $8.6 \cdot 10^{-12}$ & $10^{-9}-2 \cdot 10^{-5}$ & $1.2 \cdot 10^{-6}$ & $9.4 \cdot 10^{-7}$ & $2.1-2.6$ & 2.3 \\
\hline \multicolumn{11}{|l|}{$\mathrm{CR}$} \\
\hline C1-7 & $\mathrm{I}_{1}$ & 4.3 & $1 \cdot 10^{-10}-1 \cdot 10^{-9}$ & $5.0 \cdot 10^{-10}$ & $5.7 \cdot 10^{-9}$ & $1 \cdot 10^{-8}-1 \cdot 10^{-4}$ & $8.2 \cdot 10^{-6}$ & $6.2 \cdot 10^{-5}$ & $2.0-3.0$ & 2.1 \\
\hline $\mathrm{C} 2-2$ & $\mathrm{I}_{2}$ & 14.2 & $4.10^{-13}-8 \cdot 10^{-11}$ & $3.9 \cdot 10^{-12}$ & $3.5 \cdot 10^{-11}$ & & $1.2 \cdot 10^{-6}$ & $9.0 \cdot 10^{-5}$ & $1.4-2.7$ & 1.95 \\
\hline $\mathrm{C} 3-3$ & $\mathrm{I}_{3}$ & 0.7 & $1 \cdot 10^{-13}-2 \cdot 10^{-12}$ & $9.9 \cdot 10^{-13}$ & $1.6 \cdot 10^{-12}$ & $3 \cdot 10^{-8}-6 \cdot 10^{-5}$ & $1.5 \cdot 10^{-5}$ & $4.9 \cdot 10^{-5}$ & $1.5-3.0$ & 1.9 \\
\hline $\mathrm{C} 4-3$ & $\mathrm{I}_{4}$ & 1.4 & $4 \cdot 10^{-14}-5 \cdot 10^{-12}$ & $2.4 \cdot 10^{-12}$ & $3.0 \cdot 10^{-12}$ & $4 \cdot 10^{-8}-3 \cdot 10^{-4}$ & $1.2 \cdot 10^{-5}$ & $4.0 \cdot 10^{-5}$ & $1.9-3.0$ & 2.1 \\
\hline $\mathrm{C} 5-3$ & $\mathrm{I}_{5}$ & 1.8 & $7 \cdot 10^{-14}-9 \cdot 10^{-12}$ & $8.1 \cdot 10^{-13}$ & $1.5 \cdot 10^{-11}$ & $1 \cdot 10^{-7}-3 \cdot 10^{-5}$ & $8.9 \cdot 10^{-5}$ & $2.4 \cdot 10^{-5}$ & $1.9-3.0$ & 2.3 \\
\hline C6-3 & $\mathrm{I}_{6}$ & 0.5 & $1 \cdot 10^{-14}-4 \cdot 10^{-12}$ & $2.2 \cdot 10^{-13}$ & $1.1 \cdot 10^{-12}$ & $1 \cdot 10^{-7}-2 \cdot 10^{-5}$ & $7.7 \cdot 10^{-6}$ & $9.9 \cdot 10^{-5}$ & $1.5-2.9$ & 2.5 \\
\hline C7-3 & $\mathrm{I}_{7}$ & 0.6 & $1 \cdot 10^{-13}-1 \cdot 10^{-12}$ & $4.4 \cdot 10^{-13}$ & $8.2 \cdot 10^{-13}$ & $3 \cdot 10^{-8}-4 \cdot 10^{-6}$ & $8.5 \cdot 10^{-6}$ & $2.3 \cdot 10^{-5}$ & $2.1-3.0$ & 2.7 \\
\hline
\end{tabular}




\begin{tabular}{|c|c|c|c|c|c|}
\hline \multirow[t]{3}{*}{ Formation / associated chamber } & \multicolumn{4}{|c|}{ Amplitude on the RMS spectrum [bars] } & \multirow[t]{3}{*}{ Form ratio } \\
\hline & $\mathrm{O}_{1}$ & $\mathrm{~K}_{1}$ & $\mathrm{~S}_{2}$ & $\mathrm{M}_{2}$ & \\
\hline & $\left(1.076 \cdot 10^{-5} \mathrm{~Hz}\right)$ & $\left(1.161 \cdot 10^{-5} \mathrm{~Hz}\right)$ & $\left(2.315 \cdot 10^{-5} \mathrm{~Hz}\right)$ & $\left(2.236 \cdot 10^{-5} \mathrm{~Hz}\right)$ & \\
\hline Staffelegg Formation / $\mathrm{I}_{1}$ & $5.886 \cdot 10^{-4}$ & $6.326 \cdot 10^{-4}$ & $3.606 \cdot 10^{-4}$ & $8.353 \cdot 10^{-4}$ & 1.02 \\
\hline OPA - Shaly facies / $I_{2}$ & $1.054 \cdot 10^{-3}$ & $1.230 \cdot 10^{-3}$ & $6.848 \cdot 10^{-4}$ & $1.696 \cdot 10^{-3}$ & 0.96 \\
\hline OPA - Shaly facies / $\mathrm{I}_{2-3}$ & $1.041 \cdot 10^{-3}$ & $1.192 \cdot 10^{-3}$ & $7.390 \cdot 10^{-4}$ & $1.823 \cdot 10^{-3}$ & 0.87 \\
\hline OPA - Carbonate-rich facies $/ \mathrm{I}_{3}$ & $7.905 \cdot 10^{-4}$ & $9.553 \cdot 10^{-4}$ & $5.014 \cdot 10^{-4}$ & $1.255 \cdot 10^{-3}$ & 0.99 \\
\hline OPA - Shaly facies / $\mathrm{I}_{4}$ & $9.560 \cdot 10^{-4}$ & $1.133 \cdot 10^{-3}$ & $6.838 \cdot 10^{-4}$ & $1.701 \cdot 10^{-3}$ & 0.88 \\
\hline OPA - Shaly facies $/ \mathrm{I}_{5}$ & $8.591 \cdot 10^{-4}$ & $1.084 \cdot 10^{-4}$ & $6.546 \cdot 10^{-4}$ & $1.670 \cdot 10^{-3}$ & 0.84 \\
\hline OPA - Sandy facies $/ \mathrm{I}_{6}$ & $8.637 \cdot 10^{-4}$ & $1.205 \cdot 10^{-3}$ & $5.329 \cdot 10^{-4}$ & $1.278 \cdot 10^{-3}$ & 1.04 \\
\hline Passwang Formation / $\mathrm{I}_{7}$ & $5.200 \cdot 10^{-4}$ & $7.206 \cdot 10^{-4}$ & $2.825 \cdot 10^{-4}$ & $6.360 \cdot 10^{-4}$ & 1.35 \\
\hline
\end{tabular}




\begin{tabular}{lcccc}
\hline Formation & Chamber & $\Delta \mathrm{h}[\mathrm{bar}]$ & $\Delta \mathrm{h}[\mathrm{m}]$ & $\mathrm{S}_{\mathrm{s}}\left[\mathrm{m}^{-1}\right]$ \\
\hline Upper Toarcian - Staffelegg Formation & $\mathrm{I}_{1}$ & $8.353 \cdot 10^{-4}$ & $8.52 \cdot 10^{-3}$ & $2.35 \cdot 10^{-6}$ \\
Upper Toarcian / Lower Aalenian - Opalinus Clay - Shaly facies & $\mathrm{I}_{2}$ & $1.696 \cdot 10^{-3}$ & $1.73 \cdot 10^{-2}$ & $1.16 \cdot 10^{-6}$ \\
Upper Toarcian / Lower Aalenian - Opalinus Clay - Shaly facies & $\mathrm{I}_{2-3}$ & $1.823 \cdot 10^{-3}$ & $1.86 \cdot 10^{-2}$ & $1.08 \cdot 10^{-6}$ \\
Lower Aalenian - Opalinus Clay - Carbonate-rich facies & $\mathrm{I}_{3}$ & $1.255 \cdot 10^{-3}$ & $1.28 \cdot 10^{-2}$ & $1.56 \cdot 10^{-6}$ \\
Lower Aalenian Opalinus Clay - Shaly facies & $\mathrm{I}_{4}$ & $1.701 \cdot 10^{-3}$ & $1.73 \cdot 10^{-2}$ & $1.15 \cdot 10^{-6}$ \\
Middle Aalenian - Opalinus Clay - Shaly facies & $\mathrm{I}_{5}$ & $1.670 \cdot 10^{-3}$ & $1.70 \cdot 10^{-2}$ & $1.17 \cdot 10^{-6}$ \\
Upper Aalenian - Opalinus Clay - Sandy facies & $\mathrm{I}_{6}$ & $1.278 \cdot 10^{-3}$ & $1.32 \cdot 10^{-2}$ & $1.53 \cdot 10^{-6}$ \\
Upper Aalenian - Passwang Formation & $\mathrm{I}_{7}$ & $6.36 \cdot 10^{-4}$ & $6.49 \cdot 10^{-3}$ & $3.08 \cdot 10^{-6}$ \\
\hline
\end{tabular}




\begin{tabular}{|c|c|c|c|c|c|c|c|c|c|c|}
\hline Chamber & Coh & $\tilde{S_{\mathrm{s}}}$ & $\mathrm{A}_{\mathrm{zl}}$ & $\mathrm{A}_{z 2}$ & $\Delta \varphi$ & $\tilde{K_{v}}{ }^{A m p}$ & $\tilde{K_{v}} \Delta^{\Delta \varphi}$ & B & $\omega$ & $\omega_{\text {water loss }}$ \\
\hline & {$[-]$} & {$\left[\mathrm{m}^{-1}\right]$} & [bar] & [bar] & [rad] & {$\left[\mathrm{m} \cdot \mathrm{s}^{-1}\right]$} & {$\left[\mathrm{m} \cdot \mathrm{s}^{-1}\right]$} & {$[-]$} & {$[-]$} & {$[-]$} \\
\hline $\mathrm{I}_{1}$ vs. $\mathrm{I}_{2}$ & 0.9985 & $1.75 \cdot 10^{-6}$ & $8.35 \cdot 10^{-4}$ & $1.70 \cdot 10^{-3}$ & -0.18220 & $4.7 \cdot 10^{-8}$ & $7.2 \cdot 10^{-7}$ & 0.2520 & 0.09 & 0.18 \\
\hline $\mathrm{I}_{2}$ vs. $\mathrm{I}_{2-3}$ & 0.9992 & $1.12 \cdot 10^{-6}$ & $1.70 \cdot 10^{-3}$ & $1.82 \cdot 10^{-3}$ & 0.03573 & $2.5 \cdot 10^{-6}$ & $1.0 \cdot 10^{-5}$ & 1.0350 & 0.24 & 0.15 \\
\hline $\mathrm{I}_{2-3}$ vs. $\mathrm{I}_{3}$ & 0.9986 & $1.32 \cdot 10^{-6}$ & $1.82 \cdot 10^{-3}$ & $1.26 \cdot 10^{-3}$ & 0.07658 & $1.4 \cdot 10^{-7}$ & $3.3 \cdot 10^{-6}$ & 0.3949 & 0.11 & 0.13 \\
\hline $\mathrm{I}_{3} \mathrm{vs} . \mathrm{I}_{4}$ & 0.9977 & $1.36 \cdot 10^{-6}$ & $1.26 \cdot 10^{-3}$ & $1.70 \cdot 10^{-3}$ & -0.06768 & $2.9 \cdot 10^{-7}$ & $5.8 \cdot 10^{-6}$ & 4.6810 & 1.33 & 0.12 \\
\hline $\mathrm{I}_{4} \mathrm{Vs} . \mathrm{I}_{5}$ & 0.9930 & $1.16 \cdot 10^{-6}$ & $1.70 \cdot 10^{-3}$ & $1.67 \cdot 10^{-3}$ & 0.02158 & $5.7 \cdot 10^{-5}$ & $4.1 \cdot 10^{-6}$ & 0.4758 & 0.12 & 0.14 \\
\hline $\mathrm{I}_{5}$ vs. $\mathrm{I}_{6}$ & 0.9965 & $1.36 \cdot 10^{-6}$ & $1.67 \cdot 10^{-3}$ & $1.28 \cdot 10^{-3}$ & -0.05037 & $6.4 \cdot 10^{-7}$ & $1.8 \cdot 10^{-5}$ & 0.2889 & 0.08 & 0.13 \\
\hline $\mathbf{I}_{6} \mathbf{V s} . \mathbf{I}_{7}$ & 0.9965 & $2.31 \cdot 10^{-6}$ & $1.28 \cdot 10^{-3}$ & $6.36 \cdot 10^{-3}$ & 0.50810 & $3.9 \cdot 10^{-8}$ & $7.3 \cdot 10^{-8}$ & 1.6290 & 0.79 & 0.13 \\
\hline
\end{tabular}


Cover Letter

Click here to download Cover Letter Cover.docx

Mont Terri Special Issue 2017 